\title{
Aggregate Demand and Long-Run Unemployment
}

WHAT DETERMINES the unemployment rate? In answering this question, mainstream economics draws a sharp distinction between the short run and the long run. According to the conventional view, short-run movements in unemployment are strongly influenced by monetary policy and other determinants of aggregate demand. In the long run, however, unemployment returns to a natural rate or NAIRU (the nonaccelerating-inflation rate of unemployment), which is determined by labor market frictions. The NAIRU can change over time for microeconomic reasons, such as changes in labor market institutions. But the conventional wisdom holds that the NAIRU is unaffected by aggregate demand, and thus that demand does not influence long-run unemployment trends.

This paper argues that this conventional view is wrong. Monetary policy and other determinants of aggregate demand have strong effects on longrun as well as short-run movements in unemployment. And this is not just a theoretical point. Over the last twenty years the behavior of demand accounts for much of the differences across countries in the evolution of unemployment.

Aggregate demand has long-run effects on unemployment because of what Olivier Blanchard and Lawrence Summers have called hysteresis. ${ }^{1}$ At a given point in time, there exists a NAIRU: pushing unemployment below

I am grateful for research assistance from Julie Smith, Rebecca Zarutskie, and Huiyan Zhang; for help with data from the Economics Department of the Organization for Economic Cooperation and Development, especially Stefano Scarpetta; for suggestions from Louis Maccini, David Romer, and members of the Brookings Panel; and for the hospitality of the Norges Bank, where this paper was completed.

1. Blanchard and Summers (1986). 
a certain level causes inflation to rise. But as demand pushes unemployment away from the current NAIRU, this causes the NAIRU itself to change over time. A number of authors (including myself) ${ }^{2}$ have presented empirical evidence in favor of hysteresis, but many students of unemployment remain unpersuaded. The broad goal of this paper is to bolster the case for hysteresis in industrial countries in the 1980s and 1990s.

This paper also documents two specific aspects of hysteresis that are important in recent history. The first concerns the role of monetary policy in determining whether hysteresis arises-whether a cyclical rise in unemployment causes a rise in the NAIRU. Here I primarily examine the early 1980s, when most member countries of the Organization for Economic Cooperation and Development (OECD) experienced recessions arising from disinflationary monetary policy. In some countries, such as the United States, the rise in unemployment was transitory; in others, including many European countries, the NAIRU rose and unemployment has remained high ever since. I argue that the reactions of policymakers to the early-1980s recessions largely explain these differences. In countries where unemployment rose only temporarily, it did so because of strongly countercyclical policy: after tight policy produced a recession to disinflate the economy, policy shifted toward expansion, reducing unemployment. In countries where unemployment rose permanently, it did so because policy remained tight in the face of the 1980s recessions.

This analysis implies that passive macroeconomic policy during a recession has a high cost: it can lead to permanently higher unemployment. And there do not appear to be substantial benefits from such inaction. I find that countries that combated recessions with expansionary policy still obtained lower inflation from the initial rise in unemployment. Countries that kept policy tight did not gain an additional reduction in inflation.

Most previous discussions of hysteresis focus on its role in explaining increases in unemployment. The second part of my analysis asks whether hysteresis works in reverse-whether demand expansions can produce permanent decreases in unemployment. Here I examine the period from 1985 through 1997, when several countries emerged as success stories in reducing unemployment. In particular, I identify four countries where unemployment has fallen substantially since 1985-Ireland, the Netherlands, Portugal, and the United Kingdom—and contrast them with coun- 
tries where unemployment has stayed high. I find that reverse hysteresis helps explain the success stories: their decreases in unemployment were caused largely by demand expansions. These expansions reflected both intentional monetary policy and unintentional overheatings of the economy caused by nonmonetary shocks. As with countercyclical responses to recessions, the costs of the demand expansions were modest. There were temporary runups in inflation, but in the end the success stories achieved both low inflation and relatively low unemployment.

Most previous authors who have discussed unemployment trends emphasize distortions in labor markets. They argue that unemployment is determined by institutions such as labor unions, unemployment insurance, and firing restrictions. I argue that the conventional wisdom overrates these factors. In explaining rises in unemployment in the early 1980s, I find that unemployment insurance plays a role: both a long duration of benefits and passive macroeconomic policy contribute to hysteresis. ${ }^{3}$ However, labor market policies are not important causes of the unemployment successes and failures since 1985 .

Most of this paper is empirical. At the end, however, I sketch a new theory of hysteresis. The central feature of the model is a Phillips curve in which only short-term unemployment affects inflation. The model captures the broad facts uncovered in the empirical work.

The rest of this paper contains four sections. The first examines why hysteresis arose in some countries but not others in the early 1980s, and it briefly considers the early 1990s as well. The second section examines the roles of labor market policies and aggregate demand in explaining why unemployment fell in some countries and remained high in others from 1985 through 1997 . The third section presents my theoretical model. The fourth section compares my results with those of previous work and discusses policy implications.

\section{The Role of Policy Responses to Recessions}

This section argues that a cyclical rise in unemployment sometimes leads to a higher NAIRU and sometimes does not. Most important,

3. Ball (1997) also finds that a long duration of unemployment benefits contributes to hysteresis. 
whether hysteresis arises depends largely on the response of monetary policy to the recession. To make this point, I focus mainly on the early 1980 s, a period when most OECD countries experienced recessions as a result of anti-inflationary monetary policy. Although the recessions were initially similar, central banks in different countries responded to them differently. In some countries, central banks responded with sharp monetary easing. These policies produced spurts of rapid growth that brought output back to trend and reduced unemployment to roughly its level before the recession. In other countries, policy remained tight despite the recession because policymakers wanted to reduce inflation further or to support currencies. In these countries the recessions eventually ended, but without the spurt of rapid growth needed to bring output back to its previous trend. Unemployment stayed high and inflation eventually stabilized, implying a higher NAIRU.

The first part of this section analyzes the experience of the six countries out of the Group of Seven (G-7) large industrial countries that experienced recessions in the early 1980s (Japan did not). I emphasize these countries because they have reliable quarterly output data, which allow a precise dating of recessions and policy responses. Following Christina Romer and David Romer, ${ }^{4}$ I assess the behavior of policy by examining short-term interest rates during the recessions and by reading the historical record. The second part of the section extends the analysis to a total of seventeen OECD countries that experienced recessions in the early 1980s. Here the measurement of policy is cruder, but the larger sample is important for separating the roles of monetary policy and unemployment benefits in creating hysteresis. I also briefly consider the recessions of the 1990s, which turn out to yield less information on the determinants of hysteresis.

\section{Evidence for the G-7 Countries}

Here I identify recessions in the G-7 countries in the early 1980s and examine the responses of monetary policy. I then investigate the implications of different countries' responses for the behavior of output, unemployment, and inflation.

IDENTIFYING RECESSIONS. If one were studying the United States alone, it would be natural to identify recessions based on the standard dating by the National Bureau of Economic Research (NBER). Since I

4. Romer and Romer (1994). 
am interested in other countries as well, I devise a method for dating recessions that reproduces the NBER dates for the United States but can also be applied to other countries. I assume that a recession occurs any time real GDP falls two quarters in a row, or falls by more than 2 percent in any one quarter. (The latter criterion is needed to capture the U.S. recession of the second quarter of 1980.) The peak preceding a recession is defined as the quarter with the highest level of real GDP preceding the two quarterly declines or the one large decline; the trough of the recession is the quarter with the lowest level of GDP after the peak. For the post-World War II United States, this definition yields exactly the same eight recessions, with the same quarterly peaks and troughs, that the NBER identifies with its judgmental method.

I examine recessions with preceding peaks in any year from 1979 through 1984. Japan has no recessions in this period, Germany has one, and the other five G-7 countries have two each. Tables 1 and 2 list the dates of the recessions. In all six countries that experienced recessions, a major cause was tight monetary policy aimed at reducing inflation. Examples include the disinflation in the United States undertaken by the Federal Reserve under Chairman Paul Volcker, and the disinflation in the United Kingdom under Prime Minister Margaret Thatcher. In all these countries, the central bank raised interest rates sharply in the late 1970s or early 1980s, and inflation fell subsequently.

MEASURING POLICY RESPONSES WITH INTEREST RATES. I nOw eXamine the responses of monetary policy to the recessions. The six countries divide into two groups. The two North American countries (NA2; table 1) responded to their recessions by easing policy sharply, whereas the four European countries (E4; table 2) kept policy tight.

I first measure policy responses to recessions by examining short-term interest rates. Following Romer and Romer, ${ }^{5}$ I measure this response by the change in interest rates between the peak and the quarter after the trough. Romer and Romer find that the Fed reduced nominal and real interest rates substantially during this period in all eight of the U.S. recessions since World War II. For the early 1980s I confirm this finding for the United States, but it does not carry over to all other countries.

For a given quarter, the nominal interest rate is defined as the average of a country's treasury bill rate, which is taken from International Financial

\section{Romer and Romer (1994).}




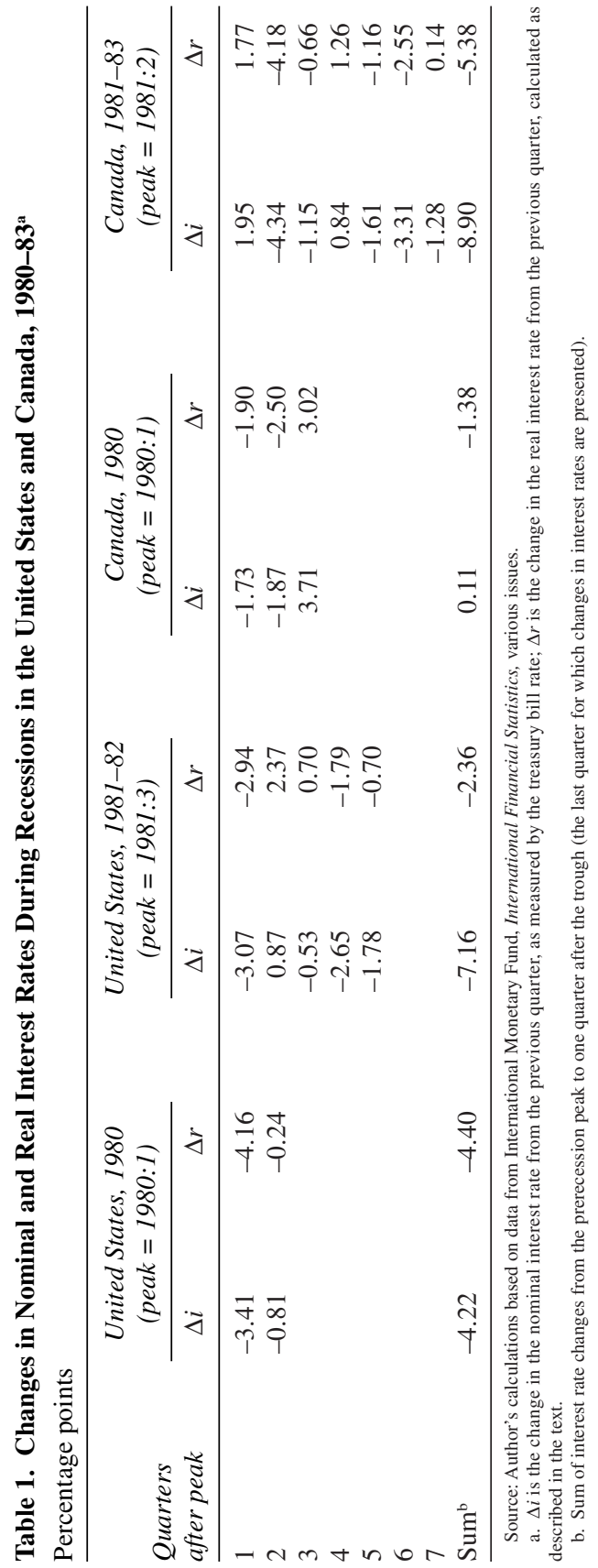




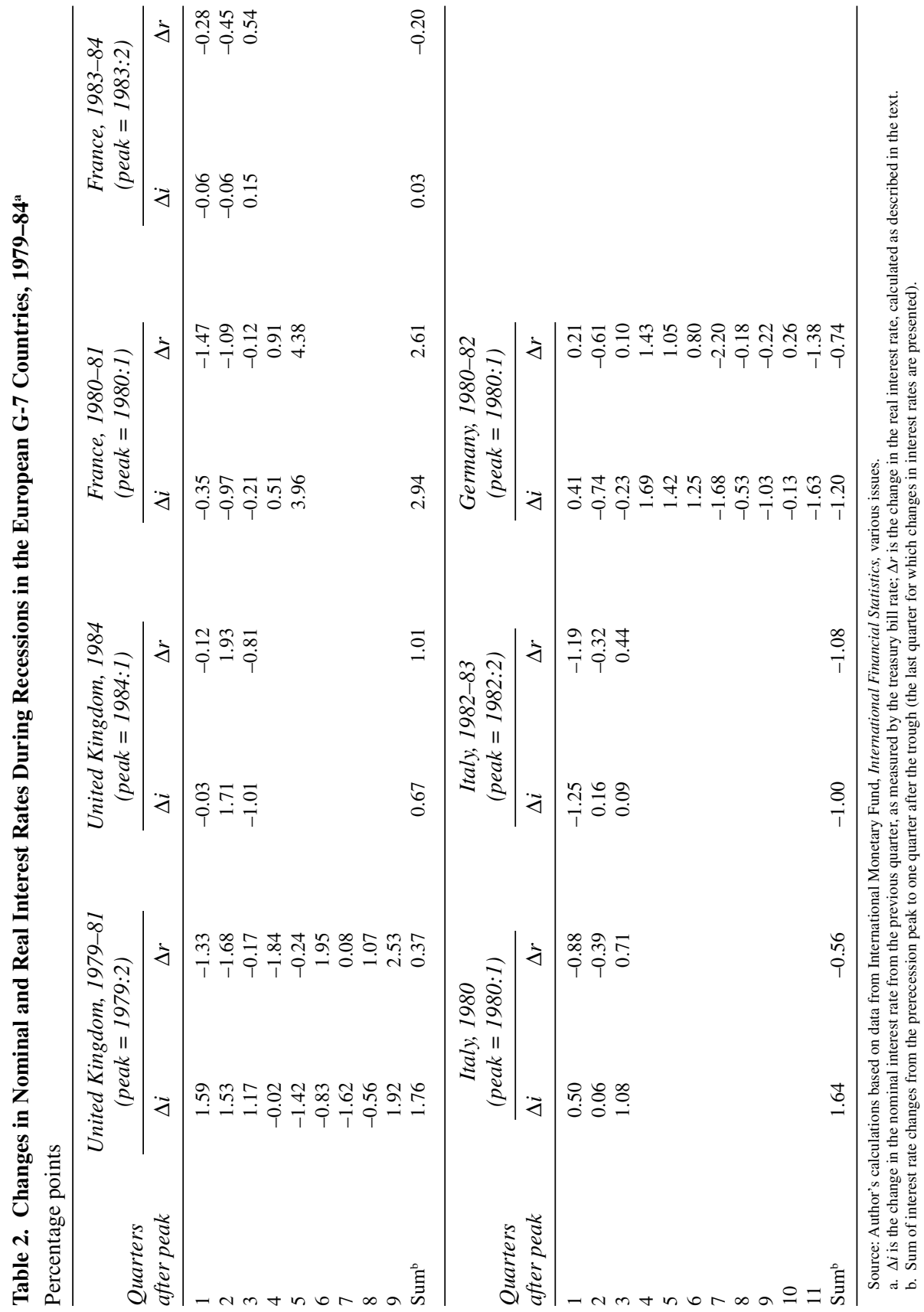


Statistics. ${ }^{6}$ Following the bulk of applied work on measuring the stance of policy, I compute the real interest rate by subtracting the previous year's rate of consumer price inflation from the current interest rate. (John Taylor and many OECD and IMF researchers, among others, have followed this approach. ${ }^{7}$ ) For quarter $t$, it is common in previous work to use the average of inflation from $t-3$ through $t$. This timing is questionable, however, since inflation for quarter $t$ is not known when interest rates are set during that quarter, although agents have some information about it. I therefore also experiment with using inflation from $t-4$ through $t-1$. The choice of timing makes some difference for the behavior of real interest rates in individual countries but does not affect the broad conclusions. In the results reported here, I compromise by using the average of the two inflation rates. ${ }^{8}$

Tables 1 and 2 present data on changes in nominal and real interest rates during the recessions of the early 1980s. Following Romer and Romer, I show the changes for each quarter and summarize the results for each recession with the total change from the peak to one quarter after the trough.

This exercise yields a sharp dichotomy between the North American countries and the European countries. In the four recessions in the NA2, the total change in the real interest rate from the peak to the quarter after the trough ranges from -1.4 to -5.4 percentage points, with an average of -3.4 percentage points. In the seven recessions in the $\mathrm{E} 4$, there is always less easing of policy, and often even a tightening: the change in the real interest rate ranges from -1.1 to +2.6 percentage points, with an average of +0.2 percentage point. Tables 1 and 2 also show that the differences in real interest rate behavior result mainly from differences in nominal interest rates rather than differences in inflation. In most cases the United States and Canada cut nominal rates sharply during recessions, whereas the European countries held them steady or raised them slightly.

6. International Monetary Fund, International Financial Statistics, various issues.

7. Taylor (1993).

8. The case in which the choice of timing makes the most difference is the second U.S. recession. In this case, the decline in the real interest rate from the peak to the quarter after the trough is 1.3 percentage points if one uses inflation from quarter $t-3$ through $t$, and 3.4 percentage points if one uses inflation from $t-4$ through $t-1$. The average of 2.4 percentage points is close to the fall in the real interest rate implied by inflation forecasts in the Fed's Greenbook. 
In the United States and Canada, the policy responses to recessions were quick. There were large cuts in nominal and real interest rates in the first quarter of each U.S. recession and within the first two quarters of each Canadian recession. These facts are perhaps surprising in light of the conventional view that policymakers in the early 1980s were focused on fighting inflation. For example, high inflation caused the Volcker Fed to tighten policy before the two U.S. recessions. But the Fed eased as soon as the recessions began, even though inflation had not yet fallen substantially.

HISTORICAL ACCOUNTS OF POLICY. Since interest rates are imperfect measures of policy stance, I have also examined the historical record. In particular, it is revealing to compare policy discussions in the United States and the United Kingdom. For the United States, Romer and Romer as well as John Boschen and Leonard Mills use the minutes of the Federal Open Market Committee (FOMC) to argue that the Fed reacted strongly to the early-1980s recessions. ${ }^{9}$ For example, in April 1980, at the start of the first recession, the FOMC reduced interest rates because it did not want to "exacerbate recessionary tendencies in the economy." In June 1982, during the second recession, it expressed an intention "to provide sufficient monetary growth to encourage recovery in economic activity."

Examination of the Bank of England Quarterly Bulletin for the early 1980s does not reveal anti-recessionary rhetoric like that of the Fed. Instead the discussions emphasize the importance of staying the course in fighting inflation, even at the cost of recession. In the June 1980 issue, policymakers seem resigned to a recession: "Rising inflation against a policy of monetary restraint is bound to worsen prospects for the real economy in the short term. Signs of a slowdown in demand and output accumulated through 1979, and substantial falls in output and employment are likely as the recession develops." 10

Despite this assessment, the bulletin states that:

Government fiscal and monetary policies are designed to bring about a progressive reduction in inflation, and need to be continued till that end is accomplished: a less restrictive policy would clearly be inappropriate at a time when inflation is so high. Weaker demand should help to moderate inflation; but recession is coming later than expected, and the full effects on wages and prices

9. Romer and Romer (1994); Boschen and Mills (1991).

10. Bank of England Quarterly Bulletin, June 1980, p. 119. 
may not be seen for some time. The influence of monetary restraint can only be gradual and pervasive, with effects to be looked for over a period of years. ${ }^{11}$

In later issues the bulletin discusses the deepening recession but still takes it for granted that policy must be kept tight to reduce inflation. In December 1980 it argues that "policy has been effective in slowing down inflation. It will be important for the future to maintain the thrust of monetary restraint." 12

I have also examined policy in the early 1980s in the other European countries, mainly using the OECD's economic surveys of its member countries. The continental European countries also failed to ease policy in the face of recessions. Often the reason was a desire to support currencies within the European Monetary System (EMS). For example, the 1982-83 survey for France reports that:

although one of the authorities' main objectives was to bring domestic interest rates down so as to ensure conditions conducive to an upturn in economic activity, their room for manoeuvre was strictly limited by the pressures of the foreign exchange market in an international context of high interest rates. ${ }^{13}$

Pressure on the franc led to sharp interest rate rises in the middle of 1981 and again in early 1982 and kept interest rates high thereafter. ${ }^{14}$

OUTPUT DURING RECOVERIES. To understand unemployment, it is useful first to examine the behavior of output. In doing so, I again take Romer and Romer's analysis of the United States as a starting point. Romer and Romer discuss the stylized fact, identified by Daniel Sichel, among others, ${ }^{15}$ that U.S. recessions are usually followed by a "recovery" period in which growth is well above normal. This extra growth returns output to its previous trend after the recession pushes it below trend. Romer and

11. Bank of England Quarterly Bulletin, June 1980, p. 138.

12. Bank of England Quarterly Bulletin, December 1980, p. 406.

13. OECD (1983, pp. 44-45).

14. In his comment on this paper, N. Gregory Mankiw accepts my evidence that countries with tight monetary policy suffered relatively large increases in the NAIRU. He argues, however, that causality may run from exogenous NAIRU movements to the behavior of policy. His story is plausible a priori, but the historical record refutes his interpretation of policy. For example, the reason that France failed to ease policy as the United States did was not concern over a rising NAIRU, but rather the constraint from its exchange rate regime. And the behavior of the United Kingdom is explained simply by extreme policy objectives. The Bank of England kept policy tight because it viewed economic recovery as much less important than disinflation.

15. Sichel (1994). 
Romer argue that rapid recoveries are generated mainly by the expansionary response of monetary policy to recessions. From their estimates of the impact of monetary policy, they argue that growth following recessions would not be substantially above its average level if policy did not ease.

As we have seen, the E4 countries did not ease policy when recessions occurred in the early 1980s. Thus Romer and Romer's explanation for U.S. recoveries suggests that output should not have grown rapidly after the $\mathrm{E} 4$ recessions. And this is the case, as demonstrated by tables 3 and 4, which show growth in the NA2 and the E4, respectively, after the troughs of recessions in the early 1980s. The tables show average annualized growth (measured as the change in the logarithm of output) for the first four quarters and the first eight quarters after the trough. In the United States and Canada, growth picks up strongly after each recession. After the first recession in these countries, growth is interrupted by the second recession. But after the second recession there is a sustained growth spurt: average annualized growth in the eight quarters after the second trough is 5.2 percent in the United States and 6.2 percent in Canada. In the European recoveries, by contrast, growth is not much above estimates of its long-run trend: with one exception (the second U.K. recession), average growth in the eight quarters after a trough is less than 3 percent.

The absence of strong recoveries in the E4 suggests that output in these countries does not return quickly to its previous trend after a recession: the level of output stays low for a long time, if not forever. Tables 3 and 4 confirm this by showing average growth from the first cyclical peak to twenty quarters and forty quarters after the peak. In the United States and

Table 3. Output Growth During Recoveries from Recession in the United States and Canada, 1980-83

Percent change (annual rate)

\begin{tabular}{lcccc}
\hline Period & $\begin{array}{c}\text { United States, } \\
1980\end{array}$ & $\begin{array}{c}\text { United States, } \\
\text { 1981-82 }\end{array}$ & $\begin{array}{c}\text { Canada, } \\
1980\end{array}$ & $\begin{array}{c}\text { Canada, } \\
1981-83\end{array}$ \\
\hline Short run & & & & \\
$\quad$ First 4 quarters after trough & & & & \\
First 8 quarters after trough & 2.95 & 4.94 & 4.43 & 6.27 \\
Long run & 0.51 & 5.21 & 0.34 & 6.22 \\
$\quad$ First 20 quarters after peak & 1.94 & & & \\
$\quad$ First 40 quarters after peak & 2.44 & & 2.59 & \\
\hline
\end{tabular}

Source: Author's calculations based on data from International Monetary Fund, International Financial Statistics, various issues. a. Peaks and troughs are as defined in the text. 
Table 4. Output Growth During Recoveries from Recession in the European G-7 Countries, 1979-84

Percent change (annual rate)

\begin{tabular}{|c|c|c|c|c|}
\hline Period & $\begin{array}{c}\text { United } \\
\text { Kingdom, } \\
\text { 1979-81 }\end{array}$ & $\begin{array}{c}\text { United } \\
\text { Kingdom, } \\
1984\end{array}$ & $\begin{array}{l}\text { France, } \\
\text { 1980-81 }\end{array}$ & $\begin{array}{l}\text { France, } \\
1983-84\end{array}$ \\
\hline \multicolumn{5}{|l|}{ Short run } \\
\hline First 4 quarters after trough ${ }^{\mathrm{a}}$ & 2.39 & 4.42 & 2.78 & 1.50 \\
\hline First 8 quarters after trough & 2.67 & 4.41 & 1.86 & 1.98 \\
\hline \multicolumn{5}{|l|}{ Long run } \\
\hline First 20 quarters after peak & 0.35 & & 0.48 & \\
\hline \multirow[t]{2}{*}{ First 40 quarters after peak } & 2.18 & & 1.90 & \\
\hline & $\begin{array}{l}\text { Italy, } \\
1980\end{array}$ & $\begin{array}{c}\text { Italy, } \\
1982-83\end{array}$ & $\begin{array}{c}\text { Germany, } \\
1980-82\end{array}$ & \\
\hline \multicolumn{5}{|l|}{ Short run } \\
\hline First 4 quarters after trough & 1.39 & 2.92 & 2.17 & \\
\hline First 8 quarters after trough & 0.66 & 2.13 & 2.99 & \\
\hline \multicolumn{5}{|l|}{ Long run } \\
\hline First 20 quarters after peak & 1.07 & & 0.63 & \\
\hline First 40 quarters after peak & 2.14 & & 1.93 & \\
\hline
\end{tabular}

Canada the annualized growth rates over twenty quarters are 1.9 percent and 2.6 percent, respectively - not too far from estimates of growth in potential output. Thus the recessions that pushed output below potential were balanced by recoveries that brought it back. In the E4, in contrast, the twenty-quarter growth rates range from 0.4 percent to 1.1 percent. This slow growth implies that, five years after the first peak, output is far below the level implied by its previous trend. Even after forty quarters, the average growth rate in the $\mathrm{E} 4$ is 0.67 percentage point below the average for the United States and Canada. This implies a difference in output levels of 6.7 percent.

UNEMPLOYMENT AND INFLATION. Okun's law implies that deviations of output from trend push unemployment in the opposite direction. It implies that the recession-recovery pattern in the NA2 should produce a rise in unemployment and then a fall to around the initial level. The output pattern in Europe, with a recession followed by a return of normal growth and a still-low level of output, should cause unemployment to rise and then stay high. These predictions, too, are borne out by the data. Figure 1 shows 
Figure 1. Change in Unemployment Rate after Prerecession Peak in the G-7 Countries, 1979-88

Percentage points

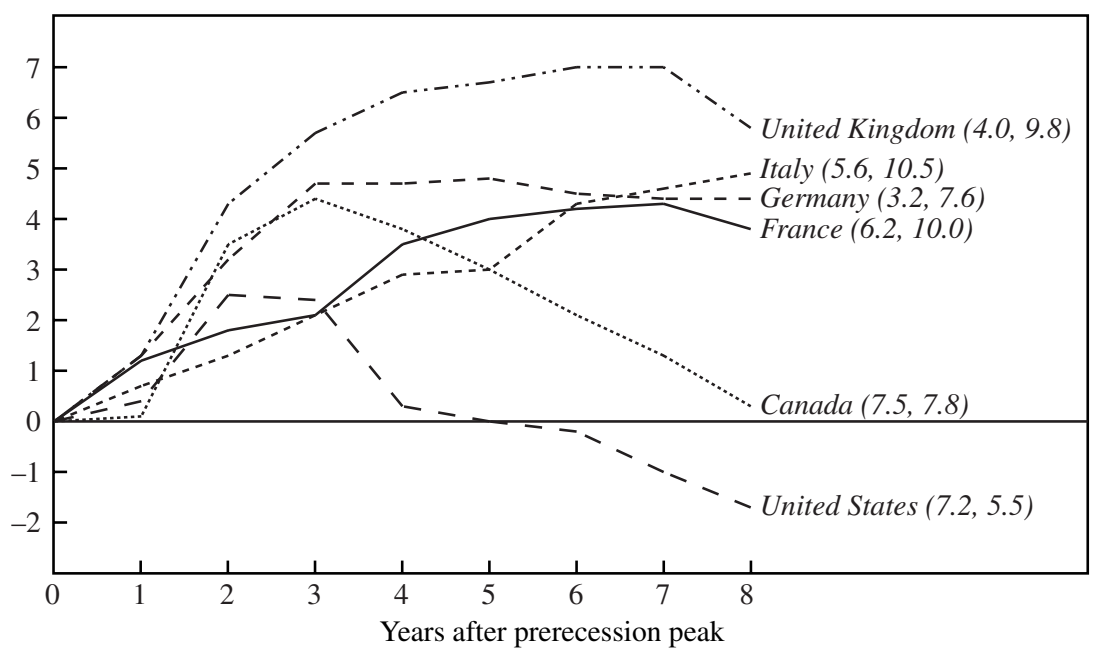

Source: OECD Economic Outlook, June 1996.

a. The first number in parentheses after the country name is the unemployment rate in the peak year, and the second is the rate eight years after the peak.

annual unemployment rates in all six countries from the year of the first cyclical peak until eight years later. (The first peak occurs in 1979 in the United Kingdom and in 1980 in the other countries.) In the NA2 unemployment rises but then returns to its initial level or below, whereas it stays high in the E4.

If each country had a constant NAIRU, a rise in unemployment would cause a fall in inflation. In the countries where unemployment stayed high, inflation would fall indefinitely. As figure 2 shows, however, this is not what happened. For each country this figure shows the behavior of trend inflation from the quarter of the first cyclical peak to eight years later. Trend inflation is defined, as in my previous work, ${ }^{16}$ as a centered ninequarter moving average of consumer price inflation. The figure shows that the six countries experienced qualitatively similar disinflations: inflation fell substantially in the first half of the 1980s and then stabilized. The high unemployment in the E4 eventually stopped putting downward 
Figure 2. Change in Trend Inflation after Prerecession Peak in the G-7 Countries, 1979-88 ${ }^{a}$

Percentage points

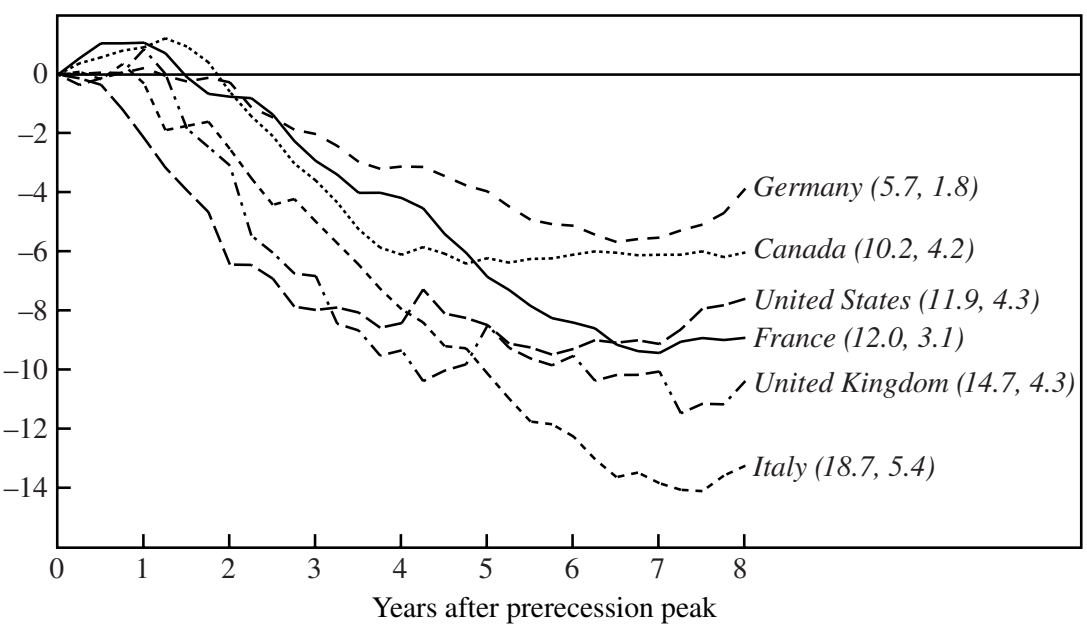

Source: Author's calculations based on data from International Monetary Fund, International Financial Statistics, various issues.

a. Trend inflation is defined as a centered nine-quarter moving average of consumer price inflation. The first number in parentheses after the country name is the trend inflation rate in the peak quarter, and the second is the rate eight years after the peak quarter.

pressure on inflation. Indeed, the disinflation gains from permanently higher unemployment in the E4 are not dramatically greater than those from temporarily high unemployment in the NA2. As the figure shows, the decrease in inflation varies within both groups; the average decrease over eight years is 9.1 percentage points for the $\mathrm{E} 4$ and 6.8 percentage points for the NA2.

When unemployment rises permanently without inflation constantly falling, the NAIRU has risen. To confirm this idea, I use estimates of the NAIRU produced by the OECD (OECD NAIRUs). ${ }^{17}$ The basic idea behind the OECD's procedure is to examine whether wage inflation is rising or falling, to determine whether the NAIRU is above or below the current level of unemployment. An initial series based on this idea is smoothed with the Hodrick-Prescott filter and ad hoc adjustments for outliers. The

17. The OECD's technique for estimating the NAIRU was devised by Elmeskov (1993) and is described in detail in Ball (1997). 
procedure yields NAIRU series that are intuitively plausible and fairly close to NAIRU estimates based on other techniques. ${ }^{18}$

Figure 3 shows estimates of the NAIRU corresponding to the unemployment rates in figure $1 .{ }^{19}$ As one would expect based on the behavior of actual unemployment, the NAIRU is fairly stable in the United States and Canada and rises substantially in the E4 (by more than 2 percentage points in each country). Most of the increases occur in the five years after the first cyclical peak of the 1980s.

The difference in the behavior of unemployment in the E4 and the NA2 is well known. Less well known is that, as documented above, there is a parallel difference in monetary policy: the NA2 responded more aggressively to the recessions of the early 1980s. If this relationship is causal, it implies a strong normative case for easing in response to recessions. When policymakers see a recession beginning, a quick easing prevents the temporary rise in unemployment from becoming permanent. Yet there is still a substantial reduction in inflation from the contractionary forces in the pipeline when the recession begins.

\section{Evidence from a Larger Sample of Countries}

Looking beyond the G-7 to a larger sample of OECD countries obviously provides more information to test my view. Another reason for examining non-G-7 countries, however, is to try to disentangle the roles of macroeconomic policy and labor market variables in explaining hysteresis. Economists who ignore hysteresis focus on labor market imperfections in explaining rising unemployment in Europe. Many believers in hysteresis also think that labor market distortions have a role. In particular, my own previous work finds that the extent of hysteresis depends on the duration of unemployment benefits: a cyclical rise in unemployment has a larger effect on the NAIRU if unemployed workers can stay on the dole

18. See Elmeskov (1993); Ball (1997).

19. I use NAIRU estimates prepared for the OECD Economic Outlook (volume 62, 1998). These extend back to 1980. For countries with output peaks in 1979, I need a NAIRU estimate for that year. To obtain one, I first use Elmeskov's technique to compute my own NAIRU series back to 1970 . I use my series to compute the change in the NAIRU from 1979 to 1980 and subtract this number from the OECD's 1980 NAIRU to get a 1979 NAIRU. (For the periods when they overlap, my series and the OECD's are similar but not identical, because of data revisions and ad hoc adjustments by the OECD.) 
Figure 3. Change in the NAIRU after Prerecession Peak in the G-7 Countries, 1979-88

Percentage points

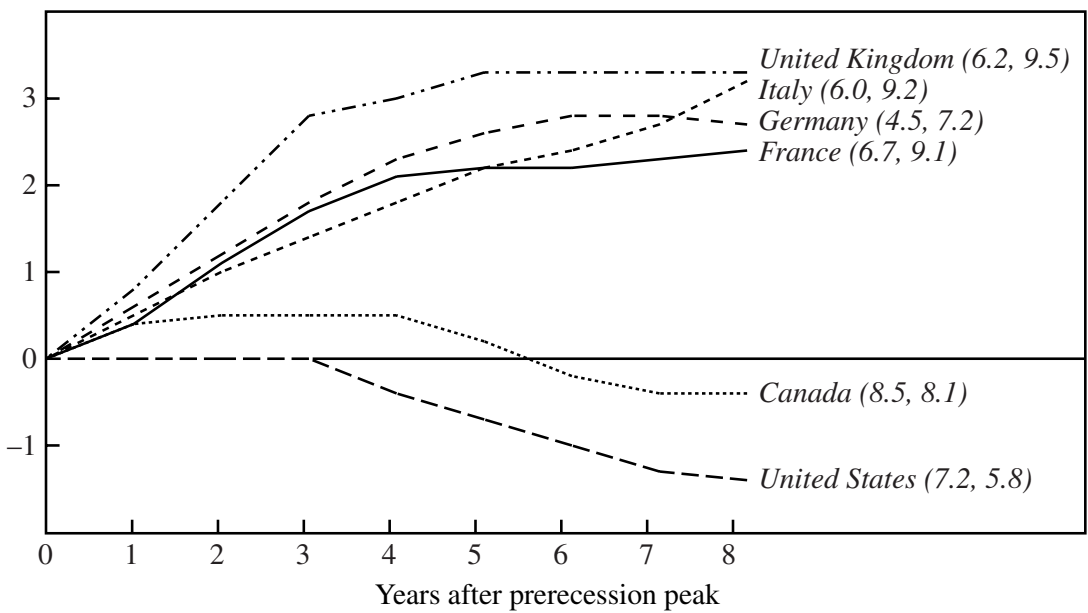

Source: Unpublished OECD data.

a. The first number in parentheses after the country name is the NAIRU in the peak year, and the second is the NAIRU eight years after the peak.

indefinitely. ${ }^{20}$ Thus differences in unemployment insurance (UI) benefits as well as in the reaction of monetary policy to recessions can explain differing trends in the NAIRU.

One cannot separate the roles of UI and monetary policy with data on the G-7 alone. As documented above, policy in the United States and Canada was more expansionary than policy in the E4 in the early 1980s. But these two countries also had shorter maximum durations of UI: half a year in both cases, compared with more than three years in France, Germany, and the United Kingdom. ${ }^{21}$ Italy had a maximum duration of six months, but this is just one case (and nonbelievers in hysteresis are quick to cite other labor market distortions, such as the high cost of firing workers, to explain Italian unemployment). Fortunately, a larger sample of countries yields substantial independent variation both in macroeconomic policy and in labor market variables, including the duration of UI.

20. Ball (1997).

21. Layard, Nickell, and Jackman (1991). 
MEASURING THE KEY VARIABLES. I start with the sample of twenty OECD countries studied by Richard Layard, Stephen Nickell, and Richard Jackman and in my own previous work. ${ }^{22}$ For one of these countries (Portugal), data for the early 1980s are missing, leaving nineteen countries. For most of these countries it is difficult to obtain reliable, seasonally adjusted data for quarterly output. Thus my analysis for the larger sample uses annual data. This requires adjustments in the procedures for dating recessions and measuring policy responses. After experimentation, I define a "recession" as one or more consecutive years of growth below 1 percent a year. Of the nineteen countries in the sample, two (Finland and Japan) had no recessions by this definition, fourteen had one recession, and three had two. This criterion appears a bit stronger than the one for selecting recessions with quarterly data, which yields two recessions for most of the G-7 countries. (There are cases of negative growth in quarterly data that do not lead to year-over-year growth of less than 1 percent.)

The analysis requires a summary statistic for policy responses to recessions to compare with the behavior of unemployment. Unfortunately, Romer and Romer's statistic - the change in the interest rate from peak to one quarter after trough - is not easily adaptable to annual data. Measuring it requires dating recessions at a quarterly frequency. Thus I use another statistic: the largest cumulative decrease in the real interest rate during any part of the recession's first year (or the average of this variable if there are two recessions). I construct this variable with quarterly data on short-term interest rates, which are available for all countries. The period of maximum easing can start and end at any point in the four quarters of the year. Because of this flexibility, my statistic has a good chance of capturing any quick reaction to a recession, regardless of when during the year the recession begins. Recall that the G-7 countries that eased policy did so quickly; thus the new variable, as well as the Romer and Romer variable, captures the fact that they eased. ${ }^{23}$

In investigating the effects of policy, I examine two unemployment variables. The first is the change in the NAIRU (again as estimated by the OECD) from the peak before the recession to five years after the peak.

22. Layard, Nickell, and Jackman (1991); Ball (1997).

23. For interest rates I use treasury bill rates where they are available. Where they are not, I use other short-term rates from International Financial Statistics: the money market rate for Austria, the call money rate for Denmark and Norway, the short-term facility rate for Ireland, and the three-month London interbank offered rate (LIBOR) for the Netherlands. 
Recall that this change is greater than 2 percentage points for all of the E4, and it is small or negative for the United States and Canada. This variable is not ideal, however, for capturing the persistence of unemployment. Different countries had recessions of differing severity in the early 1980s, and hence had different short-run increases in unemployment. Even if unemployment fed into the NAIRU to the same extent in all countries, we would observe different increases in the NAIRU. The second variable therefore adjusts for the size of the short-run rise in unemployment. It is defined as a ratio, with the change in the NAIRU from peak to five years later in the numerator and the greatest increase in actual unemployment over any period within five years after the peak in the denominator. Intuitively, the denominator measures the largest temporary runup in unemployment during the recession (or the runup after five years if unemployment is still rising at that point). The ratio captures the fraction of the rise in unemployment that feeds into the NAIRU; I call it the "degree of hysteresis." If this variable is zero (that is, if there is no change in the NAIRU), there is no hysteresis. If the ratio is one (the NAIRU rises as much as actual unemployment), there is a high degree of hysteresis. ${ }^{24}$

I examine whether the change in the NAIRU and the degree of hysteresis are related to two variables: the measure of policy easing discussed above, and the duration of unemployment benefits. The duration of benefits is taken from Layard, Nickell, and Jackman, who give data for the mid1980s. Following their method, benefits of indefinite duration are coded as four years. The duration of benefits is the only labor market variable found to influence hysteresis in my previous work. ${ }^{25} \mathrm{I}$ have checked that none of the other labor market variables analyzed by Layard, Nickell, and Jackman are significant in the regressions below.

RESULTS. Table 5 presents the regressions of the change in the NAIRU and the degree of hysteresis on the maximum policy easing and the duration of UI benefits. The maximum easing and the benefit duration have significant effects on both dependent variables. The maximum easing has its

24. In comparing the degree of hysteresis with the greatest policy easing, the following bias might arise. Suppose that the NAIRU is unaffected by monetary policy, but that a greater easing reduces the short-run increase in unemployment. In that case a greater easing reduces the denominator of the ratio I use to measure hysteresis, thus raising the ratio, even though there is no true hysteresis. This potential bias, however, goes in the wrong direction for explaining my results.

25. Ball (1997). 
Table 5. Estimated Equations for the Effects of Monetary Policy Easing and Duration of UI Benefits on the NAIRU and the Degree of Hysteresis ${ }^{\mathrm{a}}$

\begin{tabular}{lccccccc}
\hline & \multicolumn{3}{c}{$\begin{array}{c}\text { Dependent variable: } \\
\text { change in NAIRU }\end{array}$} & & \multicolumn{3}{c}{$\begin{array}{c}\text { Dependent variable: } \\
\text { degree of hysteresis }\end{array}$} \\
\cline { 2 - 3 } \cline { 7 - 9 } & $5-1$ & $5-2$ & $5-3$ & & $5-4$ & $5-5$ & $5-6$ \\
\hline Constant & 3.21 & -0.12 & 1.18 & & 0.69 & 0.12 & 0.39 \\
& $(0.66)$ & $(0.86)$ & $(0.99)$ & & $(0.09)$ & $(0.13)$ & $(0.12)$ \\
Maximum easing & -0.53 & & -0.42 & & -0.10 & & -0.09 \\
& $(0.22)$ & & $(0.20)$ & & $(0.03)$ & & $(0.02)$ \\
Duration of UI & & 0.76 & 0.64 & & 0.12 & 0.10 \\
& & $(0.28)$ & $(0.25)$ & & $(0.04)$ & $(0.03)$ \\
Adjusted $R^{2}$ & 0.23 & 0.30 & 0.43 & & 0.41 & 0.33 & 0.62 \\
\hline
\end{tabular}

Source: Author's calculations from data in Layard, Nickell, and Jackman (1991); International Monetary Fund, International Financial Statistics; unpublished OECD data.

a. Data are from a sample of nineteen OECD countries in the early 1980s. Dependent variables are defined in the text and calculated from OECD estimates of each country's NAIRU. Standard errors are in parentheses.

b. Largest cumulative decrease in the real interest rate during the first year of a recession.

strongest effects in regressions where the degree of hysteresis is the dependent variable: for a given initial rise in unemployment, a greater easing greatly reduces the effect on the NAIRU. Figure 4 shows the bivariate relation between the greatest easing and the degree of hysteresis (a $t$-statistic of 3.3 and an adjusted $R^{2}$ of 0.41 in the simple regression). Figure 5 reports a variation in which the degree of hysteresis is graphed against the largest decrease in nominal interest rates during the first year of the recession. This scatter confirms that the variation in the behavior of the real interest rate mainly reflects variation in nominal interest rates, not inflation. Figure 6 shows that there is also a significant relationship between the degree of hysteresis and benefit duration, although Italy is an outlier. When the degree of hysteresis is regressed on both the maximum easing and benefit duration, the adjusted $R^{2}$ is 0.62 . The coefficient on maximum easing implies that raising this variable from 0 to 6 (Sweden's value, the highest in the sample) reduces the degree of hysteresis by 0.54 . Reducing the duration of unemployment benefits from indefinite to half a year reduces the degree of hysteresis by 0.35 . Thus policymakers can reduce hysteresis through both macroeconomic and labor market policy, and the former has somewhat larger effects.

In figures 4 through 6, the United States and Canada stand out as the only two countries with decreases in the NAIRU, and hence negative degrees of hysteresis. The regressions explain this success by a combination of very short unemployment benefits and reactions to recessions that 
Figure 4. Change in Real Interest Rates and Degree of Hysteresis in Seventeen OECD Countries, 1979-85

Degree of hysteresis ${ }^{\mathrm{a}}$

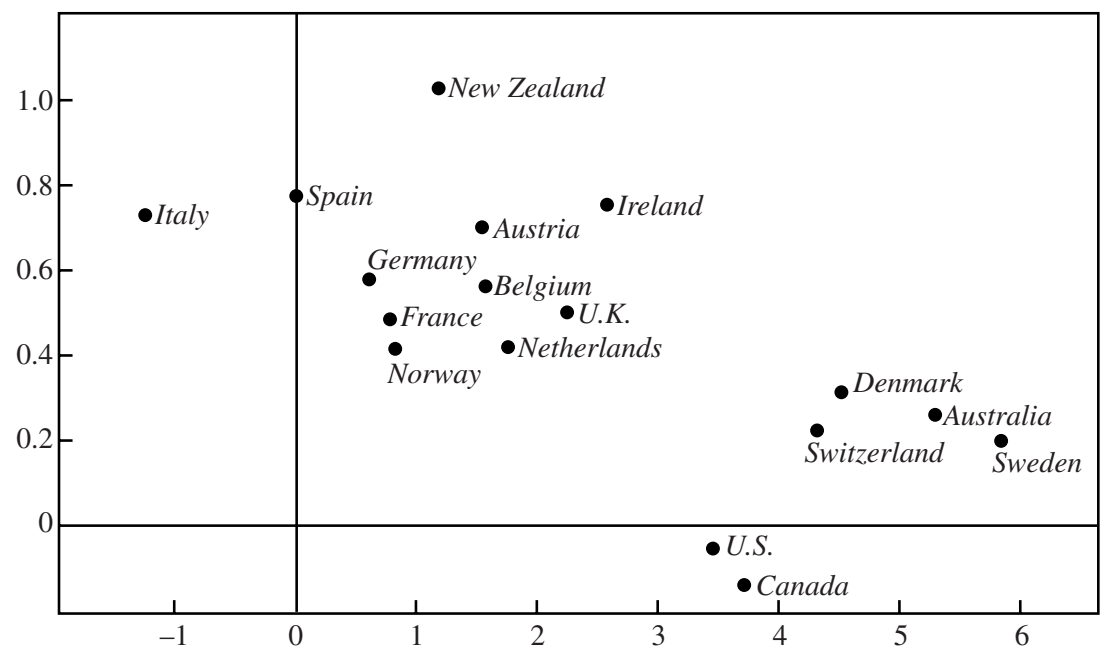

Largest cumulative decrease in real interest rate in first year of early 1980s recession (percentage points)

Source: Author's calculations based on data from OECD Economic Outlook, June 1996; International Monetary Fund, International Financial Statistics; unpublished OECD data.

a. The degree of hysteresis is a ratio, with the change in the NAIRU from the year before the first 1980s recession to five years later as the numerator, and the largest increase in actual unemployment during the same period as the denominator.

are larger than average, although not the very largest. Australia, Denmark, Sweden, and Switzerland achieved positive but small degrees of hysteresis with longer benefit durations but greater easings than the United States and Canada. Australia is noteworthy because it has indefinite benefits but still achieved a low degree of hysteresis through the second-largest policy easing.

Recall that there was little relation across the G-7 countries between policymakers' reactions to recessions and the fall in inflation. I confirm this result for the larger sample of countries by regressing the change in trend inflation from the output peak until five years later on the maximum policy easing. The adjusted $R^{2}$ is -0.03 . Thus it again appears that easing policy to prevent hysteresis has little inflationary cost.

THE EARLY 1990S. I have explored the possibility of extending the analysis to other time periods. The early 1990s, like the early 1980s, were 
Figure 5. Change in Nominal Interest Rates and Degree of Hysteresis in Seventeen OECD Countries, 1979-85

Degree of hysteresis ${ }^{\mathrm{a}}$

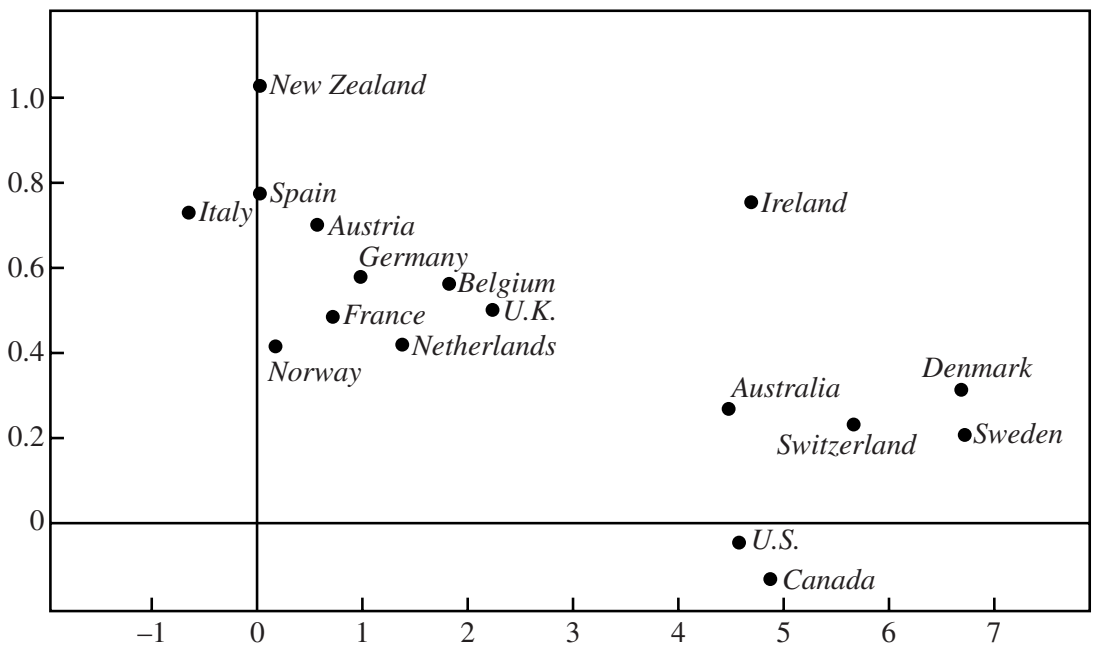

Largest cumulative decrease in nominal interest rate in first year of early 1980s recession (percentage points)

Source: Author's calculations based on data from OECD Economic Outlook, June 1996; International Monetary Fund, International Financial Statistics, various issues; unpublished OECD data

a. The degree of hysteresis is defined as in figure 4 .

a period when most OECD countries experienced recessions. At first glance it appears that this period also provides evidence that monetary policy helps determine whether hysteresis arises. By far the largest increase in the NAIRU in the 1990s occurred in Finland: the OECD NAIRU for Finland rose from 7.0 percent in 1990 to 12.8 percent in 1995. The rise in the NAIRU followed an extremely deep recession: output grew by only 0.1 percent in 1990 and then fell by 7.3 percent, 3.6 percent, and 1.2 percent in 1991, 1992, and 1993, respectively. Many accounts blame the recession on external shocks, especially the collapse of trade with the Soviet Union. In any case, monetary policy was extremely passive during the recession. The central bank held the nominal interest rate constant throughout 1990 and 1991 and raised it a percentage point in 1992. Inflation fell sharply during the recession, and so the real interest rate rose from 1.5 percent in the first quarter of 1990 to 7.0 percent in the fourth quarter 
Figure 6. Duration of Unemployment Insurance Benefits and Degree of Hysteresis in Seventeen OECD Countries, 1979-85

Degree of hysteresis ${ }^{\mathrm{a}}$

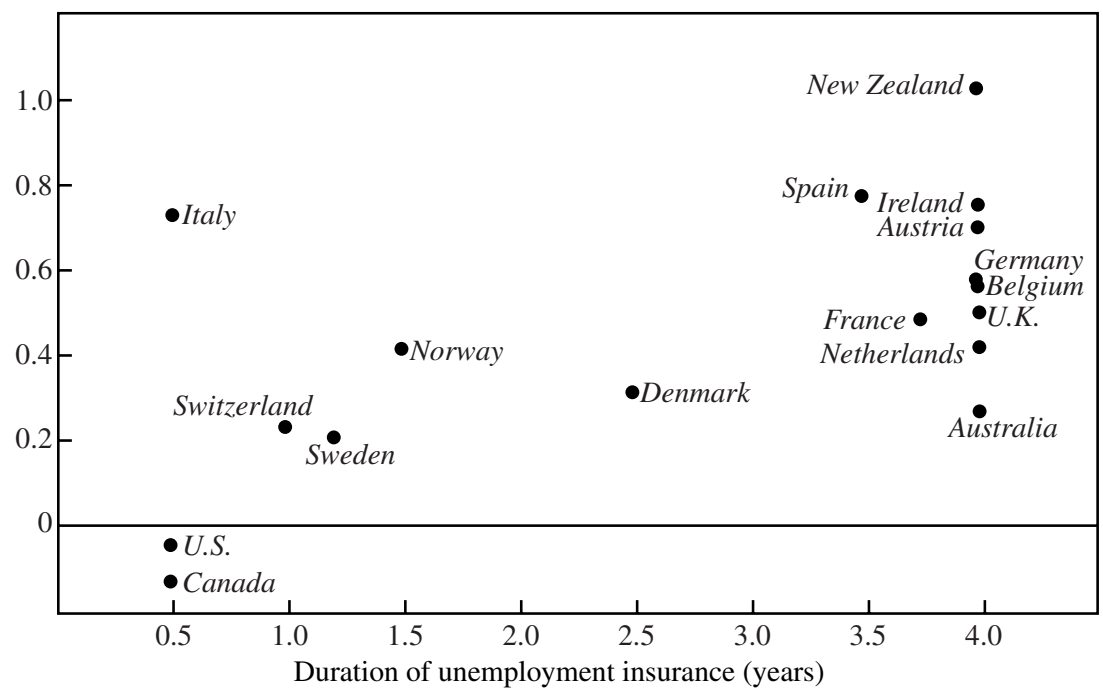

Source: Author's calculations based on data from OECD Economic Outlook, June 1996; Layard, Nickell, and Jackman (1991); unpublished OECD data.

a. The degree of hysteresis is defined as in figure 4.

of 1992. Policymakers were reluctant to cut interest rates because they were struggling to support the currency in order to remain in the EMS. Finland in the 1990s is a good example of a passive response to a recession producing a rise in the NAIRU.

The second largest rise in the NAIRU occurred in Sweden, where it rose 3.5 percentage points from 1990 to 1995 . One can tell a story about passive policy here as well, although the evidence is less clear-cut. ${ }^{26}$

26. Sweden is one of the countries where, as discussed below, the erratic behavior of policy makes it difficult to measure the degree of easing. Swedish output fell in 1990, 1991, and 1992. The largest policy easing during this recession was by 2.5 percentage points: the real interest rate fell by that amount in the first three quarters of 1990. This value for the largest easing is above average for recessions in the 1990s. In this case, however, the largest easing gives a misleading picture of the policy stance over the course of the recession. The initial easing was followed by a huge tightening: the real interest rate rose by 11.5 percentage points from the third quarter of 1990 to the third quarter of 1991, during the middle of the recession. 
On the other hand, in contrast to the early 1980s, there is no clear relation across the sample of OECD countries between hysteresis and simple measures of policy easing. The regression of the degree of hysteresis on the largest easing, defined as in table 5, yields an insignificant coefficient. The coefficient for the duration of unemployment benefits is also insignificant. The weak results reflect the fact that most changes in the NAIRU were small: after Sweden and Finland, the largest rise was 1.7 percentage points in Switzerland. Countries such as Belgium and Spain had both indefinite UI benefits and apparently passive responses to recessions, yet did not experience large rises in the NAIRU.

The explanation for these results is not clear. One possible factor is the initial level of the NAIRU. The increases in the NAIRU in the early 1980s occurred from initial levels around 6 percent or lower, whereas many countries started the 1990s with NAIRUs of 10 percent or higher. Perhaps the NAIRU does not rise without limit in response to adverse shocks, even with passive policy. Another possibility is that measures of policy easing have greater noise in the 1990s than in the 1980s. In the 1990s, policy in some countries switched erratically between tightness and ease (partly as a consequence of the 1992 crisis in the European Exchange Rate Mechanism), and this makes measures of easing less robust. In a number of countries, different measures (for example, variables based on quarterly and annual data) yield different pictures of policy.

\section{What Reduces Unemployment? 1985-97}

From the 1960s through the mid-1980s, unemployment trended upward throughout the OECD. The average unemployment rate in the OECD excluding the United States peaked at 8.0 percent in 1984-86. Although unemployment rose less in some countries than in others, no country experienced a major fall in the NAIRU. Since 1985 the experiences of the OECD countries have been more diverse. Unemployment has continued to rise in some countries but has fallen significantly in others. This experience can shed light on the question of how countries can reduce the NAIRU. In particular, one can ask whether hysteresis is symmetricwhether demand expansions reduce the NAIRU in the same way that contractions increase it. One can also examine the role of labor market reforms in reducing unemployment. 


\section{Successes and Failures in Reducing Unemployment}

The possibilities for reducing the NAIRU depend on its initial level. If unemployment is already low, it may be difficult to reduce it further. As of 1985, to take some extreme examples, there must have been some way for Spain to reduce its NAIRU below 18 percent, yet the same policies would not have reduced Switzerland's NAIRU much below 0.5 percent. In this section I focus on countries where unemployment in 1985 was high enough for policymakers to consider it a major problem. Ten countries had OECD NAIRUs above 8 percent in 1985. Figure 7 shows the evolution of the NAIRU in these countries from 1985 through 1997.

I divide the countries in figure 7 into two groups. The first group consists of the "success" countries that reduced their NAIRUs significantly: Ireland, the Netherlands, Portugal, and the United Kingdom. In these countries the NAIRU fell by amounts ranging from 2.2 to 3.0 percentage points. These are the largest NAIRU decreases in the OECD; the next largest decrease is that of the United States, which reduced its NAIRU by 0.9 percentage point from 6.5 percent in 1985 .

The second group, the "failures," has six members: Belgium, Canada, Denmark, France, Italy, and Spain. In these countries the NAIRU either rose from 1985 to 1997 or fell by a trivial amount (0.2 percentage point or less). What did these countries do wrong, or what did the four successes do right, to explain the different experiences? ${ }^{27}$

\section{Labor Market Reforms}

Before discussing the role of demand in unemployment successes and failures, I consider a factor emphasized by previous authors, namely, labor market reforms. Just as the conventional wisdom blames high unemployment on distortions in labor markets, so, too, many commentators ascribe successes in reducing unemployment to policies that reduce such distortions. For example, the success of the United Kingdom is often attributed to Thatcher's labor market reforms, and that of the Netherlands to its adoption of a "third way" in labor relations. In my view, however, the role of labor market reforms in the success stories is exaggerated.

27. If we extended the analysis through 1999, Denmark might join the successes, because unemployment there has fallen sharply in the last two years. Future work should update the analysis of Denmark. 
Figure 7. Change in the NAIRU in Ten OECD Countries, 1985-97 ${ }^{\text {a }}$

Percentage points

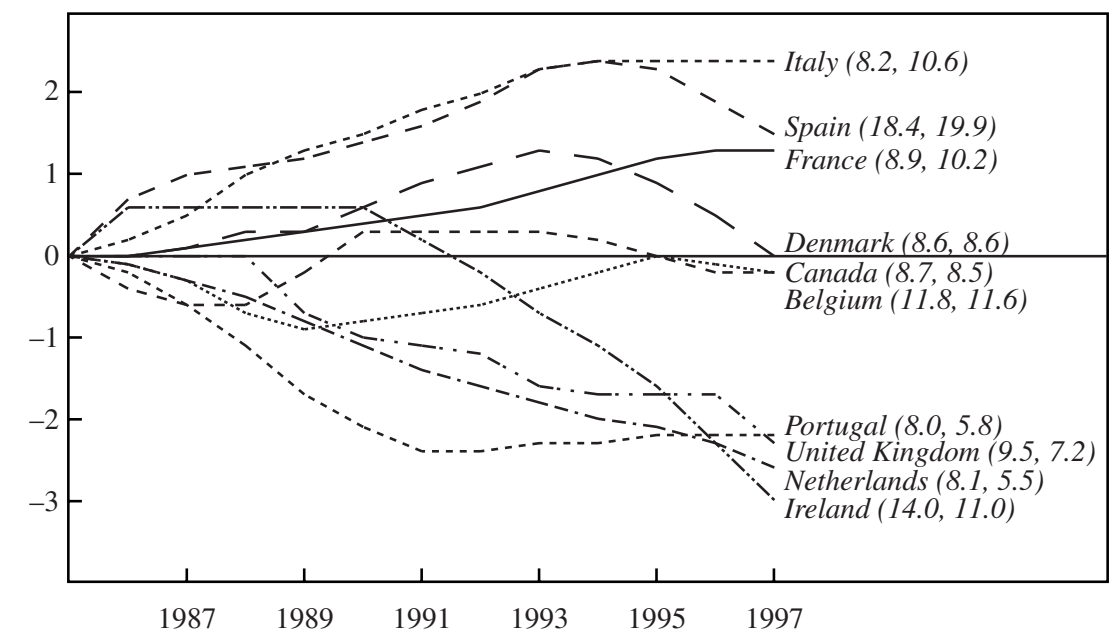

Source: Unpublished OECD data.

a. The first number in parentheses is the initial value of the NAIRU and the second is the final value.

CHANGES IN MEASURES OF LABOR MARKET DISTORTIONS. One way to investigate the role of reforms is to examine quantitative series on various labor market distortions. The most prominent series are the ones produced for the $O E C D$ Jobs Study and by Layard, Nickell, and Jackman. ${ }^{28}$ I will emphasize the OECD data because they contain the most detail about variation over time.

There is controversy about whether the OECD and the Layard, Nickell, and Jackman variables explain cross-country differences in unemployment levels. The developers of the series claim that they do, but others criticize their results as lacking robustness. ${ }^{29}$ In any case, it is clear that the series are of little help in explaining the changes over time in unemployment that I seek to understand here. The main reason is simply that the variables do not change much. For example, two well-known OECD series for 1983-95, namely, country rankings for stringency of employment pro-

28. OECD (1994a, updated in Elmeskov, Martin, and Scarpetta, 1998); Layard, Nickell, and Jackman (1991, updated in Nickell, 1997).

29. For example, Junankar and Madsen (1996); Blanchard (1997). 
tection and expenditure on active labor market policies, do not change at all. Two others, the average replacement rate for unemployment benefits and the "tax wedge," change only slightly. For these two variables, table 6 presents data for 1983 and 1995. The 1983 levels of the replacement rate range from less than 1 percent up to 56 percent of previous earnings. The largest decreases in the rate from 1983 to 1995 are by 5 percentage points in Belgium and by 4 percentage points in the United Kingdom and Spain. The largest increases are considerably larger, but not huge: Portugal and Italy, with low initial rates, increased them by 28 and 19 percentage points, respectively. Furthermore, as these examples suggest, there is no significant correlation between changes in replacement rates and changes in the NAIRU. Changes in the tax wedge are also small and uncorrelated with changes in the NAIRU. One gets similar results with the labor market variables constructed by Layard, Nickell, and Jackman. ${ }^{30}$

A partial qualification to this argument concerns the use of incomes policies. In contrast to reducing unemployment benefits or tax wedges, introducing incomes policies is arguably a step away from a Walrasian labor market. But one can make a case that incomes policies have contributed to lower unemployment in some countries. The most famous part of the Dutch experience is the Wassenaar Agreement, a 1982 accord on wage restraint accepted by the Dutch unions. Ireland also introduced national pay agreements in 1988. Thus in two of the four success countries there was a significant shift in institutions, and each occurred a few years before the NAIRU started falling. On the other hand, the other country that has adopted incomes policies since 1980 is Italy, which adopted them in 1992 without obvious benefits to date. And Spain had incomes policies in place from 1977 to 1987 , a period during which its NAIRU rose steeply. ${ }^{31}$

ANECDOTES ABOUT SUCCESS COUNTRIES. Quantitative labor market variables are crude tools for measuring labor market reform. Some important policy changes might not be captured by numbers such as those in

30. Recall that this paper uses the Layard, Nickell, and Jackman series for the duration of unemployment benefits. For most countries this variable is constant over time. For the Netherlands the reported duration decreases from indefinite in 1983-88 to two years in 1989-94. However, other sources suggest that this coding is incorrect. For example, the detailed data on 1991 benefit levels in the OECD Jobs Study show that the Netherlands has high replacement rates for the third through the fifth year of unemployment.

31. See Elmeskov, Martin, and Scarpetta (1998) for a history of incomes policies in the OECD. 
Table 6. Measures of Labor Market Distortion in Ten OECD Countries, 1983 and 1995 Percent

\begin{tabular}{|c|c|c|c|c|}
\hline \multirow[b]{2}{*}{ Country } & \multicolumn{2}{|c|}{$\begin{array}{l}\text { Replacement rate } \\
\text { of UI benefits }\end{array}$} & \multicolumn{2}{|c|}{ Tax wedge } \\
\hline & 1983 & 1995 & 1983 & 1995 \\
\hline \multicolumn{5}{|l|}{ Successes } \\
\hline Ireland & 18.2 & 26.3 & 40.1 & 38.4 \\
\hline Netherlands & 47.4 & 45.8 & 52.0 & 45.6 \\
\hline Portugal & 7.2 & 35.4 & 32.3 & 34.3 \\
\hline United Kingdom & 21.7 & 17.7 & 38.2 & 33.3 \\
\hline \multicolumn{5}{|l|}{ Failures } \\
\hline Belgium & 43.6 & 38.7 & 54.1 & 53.5 \\
\hline Canada & 29.2 & 27.2 & 25.6 & 31.4 \\
\hline Denmark & 56.3 & 67.4 & 46.5 & 45.2 \\
\hline France & 31.1 & 37.4 & 43.4 & 43.6 \\
\hline Italy & 0.5 & 19.3 & 50.5 & 49.9 \\
\hline Spain & 35.7 & 31.7 & 38.0 & 38.8 \\
\hline
\end{tabular}

Source: Unpublished OECD data.

table 6. Indeed, many discussions of the United Kingdom and the Netherlands suggest that important reforms have occurred. For example, the Economist reports that:

Once an extreme example of Eurosclerosis, some now see the Netherlands as a model for the rest of Europe. Workers have accepted small pay rises in return for more jobs; rules on part-time and temporary jobs have been relaxed; and social security taxes have been trimmed. ${ }^{32}$

In a survey of labor market rigidities in the Journal of Economic Perspectives, Horst Siebert discusses:

the approach of the British and the Dutch, where labor market institutions have been significantly overhauled, and unemployment rates have dropped as a result. Since the mid-1980s, the Netherlands implemented wage restraints, causing a fall in the real labor cost per unit of output. Moreover, it restructured the welfare state. . . Between 1985 and 1987, the government benefits for unemployment, sickness, and disability were scaled back from 80 to 70 percent of the previous wage. More restrictive definitions of disability were put in place in 1993. In 1994, employers were made directly liable for wages of sick employees in their first six weeks off the job, rather than the costs being borne by government, and employer contributions for sick leave were for the first time tied to the sick-

32. "The Good (and Bad) Model Guide," Economist, April 10, 1999, p. 68. 
ness record of the firm. From 1985-96, the Netherlands experienced strong employment growth of 1.8 percent per year. ${ }^{33}$

Siebert continues with a similar list of reforms in the United Kingdom. These include a series of laws restricting the power of unions; a weakening of employment protection (specifically, an extension from one to two years of the time until tenure); and the Restart program, which pressures UI recipients to find jobs.

I do not find such discussions convincing, for several reasons. Most obviously, they do not explain the successes of Portugal or Ireland, neither of which is commonly viewed as a major labor market reformer. Blanchard and Juan Jimeno try hard to find labor market reforms that distinguish Portugal from high-unemployment Spain, and fail. ${ }^{34}$

Second, most of the Dutch and British reforms seem minor. Changing the replacement rate from 80 percent to 70 percent and lengthening the waiting period before a worker gains employment protection are changes at the margins of labor market institutions. They move the United Kingdom and the Netherlands only a small fraction of the way toward the more flexible institutions of the United States. In my view, narratives such as Siebert's confirm rather than refute the message from quantitative indices that labor market variables do not change much over time.

Third and most important, countries that failed to reduce unemployment also adopted labor market reforms. In literally all of the ten countries I examine, policymakers recognized that high unemployment was a problem, blamed it on labor market institutions, and passed legislation to address it. In many cases the reforms seem as big or bigger than those of the United Kingdom and the Netherlands. One example is Spain. Like the Netherlands, Spain reduced its maximum replacement rate from 80 percent to 70 percent. Legislation in 1985 reduced the force of firing restrictions by allowing more temporary and part-time work. In 1992, grants to people in training programs were greatly reduced, because policymakers believed the programs drew people away from employment. A 1994 reform package included easier layoffs and less regulation of hours and job tasks. If Spanish unemployment had then fallen substantially, one could have explained this success by pointing to the same kinds of reforms used to explain the improvement in the Netherlands and the United Kingdom.

33. Siebert (1997, p. 42).

34. Blanchard and Jimeno (1995). 
Indeed, OECD country surveys of Spain from the late 1980s, when Spanish unemployment dipped, sometimes credit the 1985 reforms, ${ }^{35}$ but the surveys stop discussing these reforms when unemployment rises again in the 1990s. The Spanish reforms were not huge, and they had only modest impacts on quantitative labor market variables - but the same is true of the British and Dutch reforms.

Belgium and Canada are two more countries that have undertaken a number of reforms. OECD country surveys of Belgium report a series of UI reforms in the 1990s, ${ }^{36}$ including benefit reductions and efforts to pressure the unemployed to find jobs, as in the British Restart program. Canada also modified its UI system at several points in the 1990s, cutting benefits and directing the savings to active labor market policies.

In my view, most analysts of the success stories start with the premise that labor market reforms are the explanation, and then look for examples of reforms to support their position. They find examples, but only because all of the countries that started with high unemployment have undertaken some kind of reform. There appears to be little correlation between the extent of reforms and changes in the NAIRU.

\section{Decreases in the NAIRU and Runups in Inflation}

The rest of this section argues that demand expansions played an important role in the success stories, and that a lack of similar expansions helps explain the failures. Demand was stronger in the success countries both because of the behavior of monetary policy and because of shocks arising from nonpolicy sources. Demand expansions pushed unemployment rates in the success countries beneath their NAIRUs in 1985. Because of hysteresis, low actual unemployment pulled down the NAIRUs over time.

To tell this story, I first examine the behavior of inflation in the success and failure countries, as measured by the quarterly series for trend inflation used earlier-a nine-quarter centered moving average. If demand expansions push unemployment below the current NAIRU, then by definition inflation should rise. Thus my interpretation of the success stories implies that falling unemployment should be accompanied by rising inflation.

This prediction is borne out in three of the four success countries. To make this point, table 7 reports the magnitude and dates of the largest 
Table 7. Largest Runups in Inflation in Ten OECD Countries, 1985-97

\begin{tabular}{lcc}
\hline Country & $\begin{array}{c}\text { Largest rise in trend inflation } \\
\text { (percentage points) }^{\mathrm{a}}\end{array}$ & Period \\
\hline United Kingdom & 5.58 & $1986: 3-1989: 2$ \\
Portugal & 4.05 & $1987: 2-1990: 1$ \\
Netherlands & 3.77 & $1987: 1-1991: 2$ \\
Belgium & 2.62 & $1987: 1-1990: 1$ \\
Spain & 2.23 & $1987: 2-1989: 3$ \\
Italy & 1.92 & $1987: 3-1989: 4$ \\
Canada & 1.87 & $1985: 2-1990: 1$ \\
Denmark & 1.45 & $1986: 3-1987: 2$ \\
Ireland & 1.16 & $1987: 3-1989: 3$ \\
France & 0.91 & $1987: 1-1990: 1$ \\
\hline
\end{tabular}

Source: Author's calculations based on data from International Monetary Fund, International Financial Statistics, various issues. a. Trend inflation is calculated as a centered nine-quarter moving average of consumer price inflation.

runup in trend inflation (from any quarter to any subsequent quarter) between 1985 and 1997 in each of the success and the failure countries. All ten countries experienced an inflation runup at some point (that is, trend inflation did not decrease monotonically from 1985 to 1997). In all cases the largest runup occurred early in the period: the starting dates range from 1985 to 1987 and the end dates from 1987 to 1991, reflecting the expansions in most OECD countries in the late 1980s. The sizes of the inflation runups vary considerably across countries, however. In the six countries where unemployment did not fall substantially, the largest inflation runups range from 0.9 percentage point (France) to 2.6 percentage points (Belgium), with an average of 1.8 percentage points. In contrast, the largest runups in the Netherlands, Portugal, and the United Kingdom were 3.8, 4.1 , and 5.6 percentage points, respectively. These inflation increases in a period without adverse supply shocks imply that demand pushed unemployment below the initial NAIRU. The only success country without a large inflation runup is Ireland, where the largest runup was 1.2 percentage points.

The absence of a large inflation runup in Ireland suggests that special factors are needed to explain that country's success. Part of the story involves the timing of the fall in the NAIRU. As shown in figure 7, the NAIRU did not start to fall in Ireland until 1991, whereas it fell in the late 1980s in the Netherlands, Portugal, and the United Kingdom. Thus the three countries with the largest inflation runups in the late 1980s also had the largest falls in the NAIRU during that period. For the ten countries, 
figure 8 plots the largest inflation runup against the change in the NAIRU from 1985 to 1991, by which year all the countries had ended their largest inflation runup. The figure shows a strong relationship between inflation rises and NAIRU decreases. The relationship deteriorates somewhat when the period is extended to 1997 (not shown), because the Irish NAIRU fell from 1991 to 1997 without an inflation runup. The 1990s Irish experience is thus what requires a special story.

An important point is that the inflation runups in the Netherlands, Portugal, and the United Kingdom were not permanent. From 1985 to 1997, trend inflation rose less than 1 percentage point in the Netherlands, and it fell in the other three success countries (and in the six failures). In the Netherlands, Portugal, and the United Kingdom, inflation rose as unemployment started falling in the late 1980s. But these countries disinflated in the 1990s, and the NAIRU kept falling (in the Netherlands and the United Kingdom) or remained roughly constant (in Portugal). These facts suggest that demand expansions helped reduce the NAIRU, but that a permanent reduction in the NAIRU does not require a permanent rise in inflation.

\section{Monetary Policy and Demand in the Ten Countries}

Next I examine the economic histories of the ten countries to learn more about the causes of unemployment changes. I rely primarily on discussions in the OECD country surveys and on data on interest rates and other variables.

The analysis yields two broad conclusions. First, as suggested by the inflation evidence, most of the success countries experienced demand expansions that reduced unemployment in the late 1980s. These expansions were not caused by intentional easings of monetary policy. Instead, the economies overheated because of a variety of nonmonetary shocks to demand.

Second, differences in monetary policy also help explain unemployment successes and failures. The details of policy differ considerably from country to country, but overall policy was tighter in the failure countries. The success countries sometimes tightened policy, but only when the economy was overheating and inflation was rising. Indeed, policymakers were often slow to tighten in these situations. And when inflation stopped rising, policy eased. In contrast, the failure countries tightened policy during peri- 
Figure 8. Inflation Runups and Changes in the NAIRU in Ten OECD Countries, 1985-91

Change in NAIRU (percentage points)

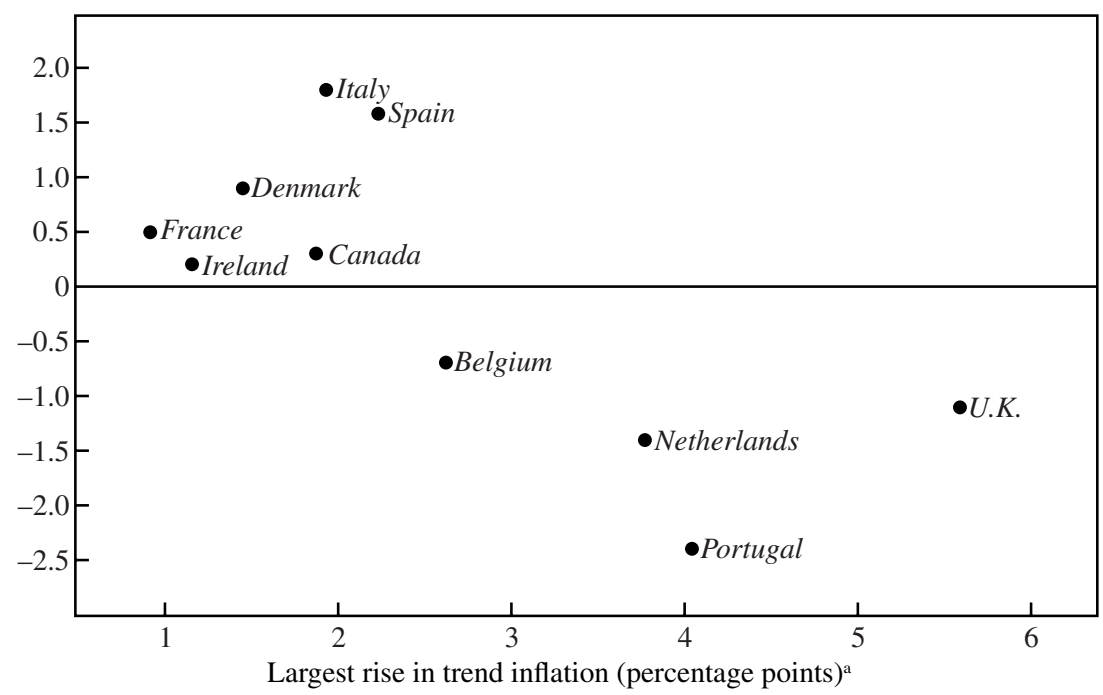

Source: Author's calculations from data in International Monetary Fund, International Financial Statistics, various issues; unpublished OECD data.

a. Trend inflation is defined as a centered nine-quarter moving average of consumer price inflation.

ods of stable or falling inflation and kept policy tight for substantial periods after recessions began. As in the early 1980s, tight policy was motivated by the desire to reduce inflation and to support currencies.

Figures 9 and 10 present some of the data that I use in the discussion. For each country I show the path of a five-quarter moving average of the real interest rate, as defined above. This interest rate series shows trends in monetary policy toward tightness or ease. The figures also show the point at which trend inflation peaked in each country after its largest runup (the solid vertical line), the output peak before each recession (the dashed vertical line), and, for the four successes, the period when the NAIRU was decreasing. Recessions are dated with quarterly data for the G-7 countries and with annual data for the other countries, using the methods described above.

UNITED KINGDOM. The United Kingdom experienced a strong, demand-driven expansion in the late 1980s. From 1986 through 1988, 
Figure 9. Trend Real Interest Rates in the Four OECD "Success" Countries, 1985-97"

United Kingdom

Percent per year

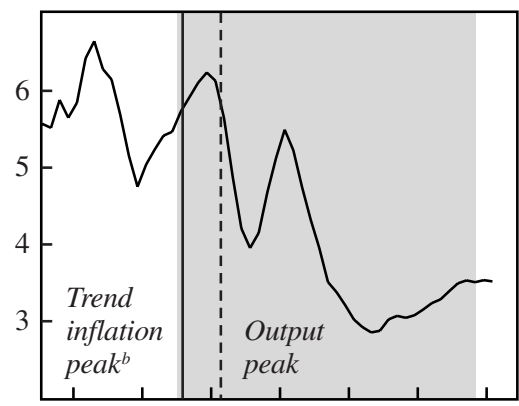

1986198819901992199419961998
Portugal

Percent per year

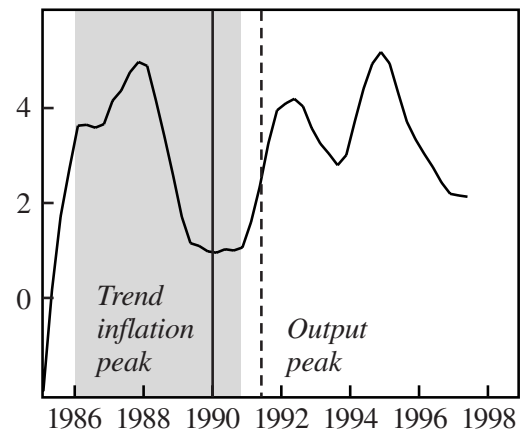

Ireland

Percent per year

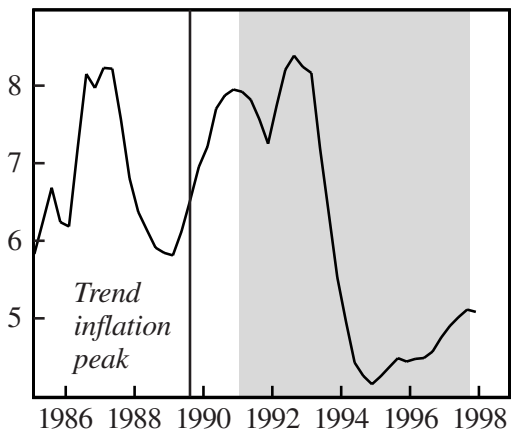

Source: Author's calculations based on International Monetary Fund, International Financial Statistics, various issues.

a. The trend real interest rate is a centered five-quarter moving average of the real interest rate as defined in the text. Shading represents periods during which the NAIRU was falling.

b. Trend inflation is a centered nine-quarter moving average of consumer price inflation.

annual growth averaged 4.7 percent. Chapter titles in the OECD surveys of the country change from "A Booming Economy" (in the 1987/88 survey) to "An Overheating Economy" (in the 1988/89 survey). ${ }^{37}$ The consensus explanation for the expansion was a boom in borrowing, and hence in consumption and investment, due to a combination of financial liberalization, high confidence, and high asset prices. Fiscal policy was also expansion- 
Figure 10. Trend Real Interest Rates in the Six OECD "Failure" Countries, 1985-98"

France

Percent per year

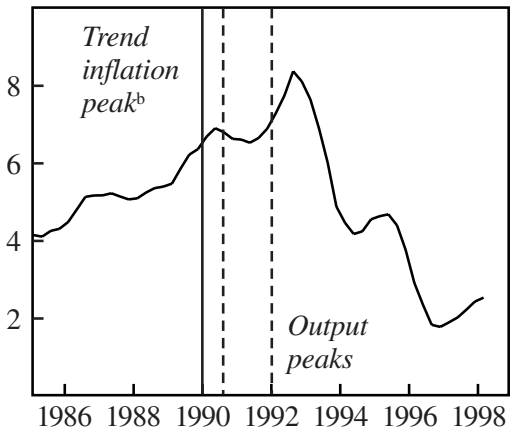

Belgium

Percent per year

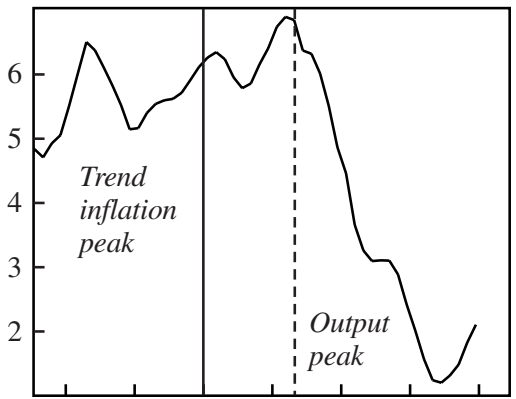

1986198819901992199419961998

Canada

Percent per year

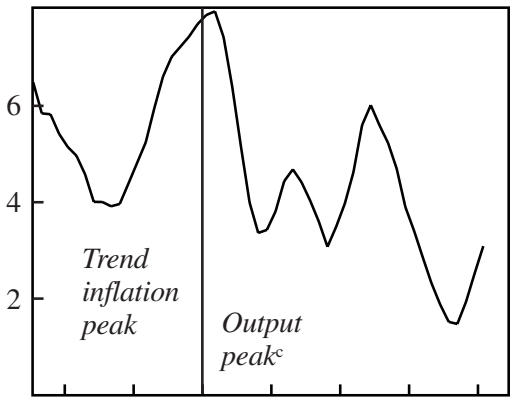

1986198819901992199419961998
Italy

Percent per year

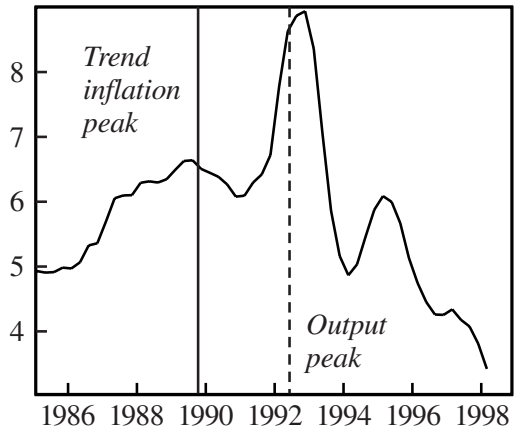

Denmark

Percent per year

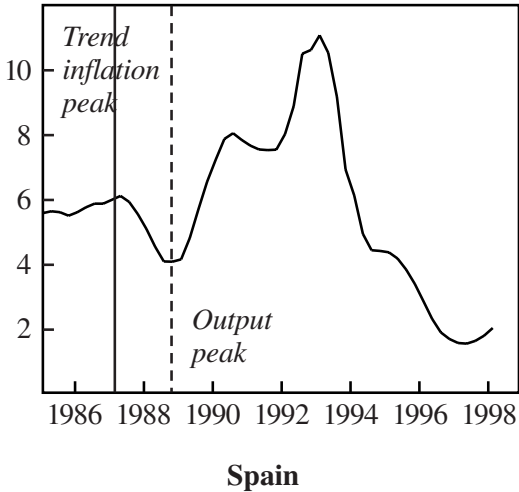

Percent per year

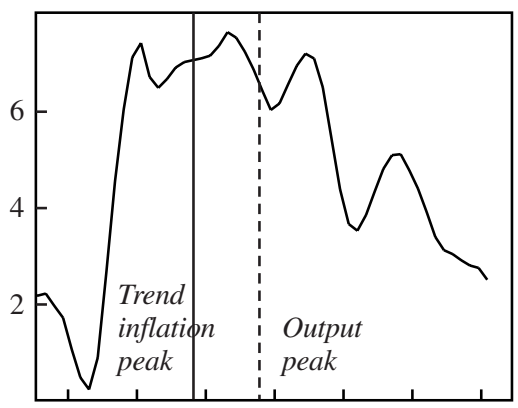

1986198819901992199419961998

Source: Author's calculations based on International Monetary Fund, International Financial Statistics, various issues.

a. The trend real interest rate is defined as in figure 9.

b. Trend inflation is defined as in figure 9 .

c. Same quarter as trend inflation peak. 
ary. The Bank of England was slow to recognize the overheating because it overestimated potential output. Thus it did not tighten policy until after inflation had started to rise. In figure 9 the smoothed real interest rate does not turn up until 1988.

Policy finally tightened in 1988 and 1989; as a result, trend inflation peaked in 1989 and a recession began in 1990. Shortly before the recession, policy as measured by the trend interest rate started to ease. The OECD surveys also report substantial easing in response to the recession. The policy easing was interrupted, but only temporarily, by efforts to support the pound. When the United Kingdom left the EMS in 1992, the interest rate resumed its downward course and the pound fell sharply, producing rapid growth. ${ }^{38}$

Actual unemployment fell sharply in the late 1980s expansion, and the OECD NAIRU for the United Kingdom began drifting down. The monetary tightening in the late 1980s and loosening in the early 1990s produced a temporary rise in unemployment, but the NAIRU continued to fall. Thus the experience of the United Kingdom in the early 1990s was like that of the United States in the early 1980s: policy easing in response to a recession prevented hysteresis. The recession nonetheless reduced inflation, reversing the inflation runup of the late 1980s.

PORTUGAL. Portugal also overheated in the late 1980s: output grew at an annual rate of 5.0 percent in 1986-90 as inflation rose and unemployment fell. Here the causes included expansionary fiscal policy and accession to the European Union, which produced transfers to the government and an investment boom financed by capital inflows. As in the United Kingdom, monetary policy failed to offset the demand expansion. For Portugal in the 1980s, interest rates are a poor guide to the stance of policy, because quantitative credit controls were the main policy tool. Portugal tried to tighten policy to reduce demand, but capital inflows reduced the effectiveness of credit controls.

38. We can also measure the policy response to the early-1990s recession using methods used earlier in this paper. The largest monetary easing as defined in table 5 was 3.9 percentage points: the real interest rate fell that much from the first quarter to the fourth quarter of 1990. This value of the largest easing is the highest for any OECD country in the early 1990s. A caveat is that, as discussed above, measures of easing are not robust in the early 1990s. When one dates the recession with quarterly data, as in tables 1 and 2, the fall in the real interest rate from peak to one quarter after the trough is only 0.6 percentage point. On the other hand, the fall from peak to three quarters after the trough (the fourth quarter of 1992, the quarter after the United Kingdom left the EMS) is 2.6 percentage points. 
Near the inflation peak in 1990, Portugal joined the EMS and switched to the interest rate as its policy instrument. It tightened policy, producing a recession and falling inflation. At that point Portugal faced the typical conflict between a desire for easier policy to promote recovery and a desire to support the currency. OECD surveys from the early 1990s show Portugal struggling to balance these objectives. ${ }^{39}$ The country took a middleof-the-road course, preferring exchange market interventions to interest rate increases, and devaluing several times, but remaining in the EMS. This middling policy produced a middling outcome for unemployment. Actual unemployment rose sharply and then fell somewhat. The NAIRU did not continue to fall in the 1990s, as in the United Kingdom, but Portugal did not give up the gains from the late-1980s expansion.

NETHERLANDS. The Netherlands experienced a long expansion starting in the mid-1980s but never overheated as much as did the United Kingdom or Portugal. Trend inflation rose slowly from -0.5 percent to 3.2 percent over four years (from the first quarter of 1987 to the second quarter of 1991). Rising inflation did not provoke an immediate policy response, however, because the level of inflation was still low. The expansion was reinforced in the early 1990s by tax cuts and the reunification boom in nearby Germany. Thus strong growth continued through 1992, whereas most of the OECD countries were in recession by 1990 or 1991. In addition, the boom ended with a soft landing: growth slowed below 1 percent in 1993 but never became negative. This experience reflects the fact that the Netherlands' business cycle was aligned with Germany's, so that mimicking German monetary policy in order to remain in the EMS was not costly. Since the economy was strong in 1991-92, it was appropriate to raise interest rates along with Germany; the Netherlands avoided the dilemma of France and the United Kingdom, where the need for tightening came when the economy was already in recession.

Thus the story of the Netherlands is not one of dramatic overheating, but rather of a long expansion and an absence of the sharp recessions that occurred in most OECD countries. This averages out to a high level of demand stimulus over 1985-97. This story fits the behavior of inflation: the Netherlands is the only one of the ten countries, successes or failures, where trend inflation rose from 1985 to 1997 (albeit slightly). (To return to an earlier point: rising inflation is not what one would expect if the

39. See, for example, OECD (1995, pp. 25-28). 
Wassenaar Agreement on wage restraint were really what is special about the Netherlands.)

THE SIX FAILURES. As suggested by their small inflation runups, the six failure countries did not experience overheatings like those in the success countries. Nonetheless, they all tightened monetary policy at various points. For four of the failures-Belgium, Denmark, France, and Italythe contractionary stance of policy is clear from the interest rate series in figure 10. These countries saw sharp increases in rates that occurred largely after the mild runups in inflation, when inflation was stable or falling. These tightenings were motivated by exchange rate concerns and desires for further disinflation. In the success countries, by contrast, tightenings occurred only when inflation was rising substantially.

In the cases of Canada and Spain, the interest rates in figure 10 do not tell a clear story. However, historical accounts make it clear that these countries pursued highly contractionary policies. The Bank of Canada adopted its famous price stability goal in 1989 and reduced inflation by almost 5 percentage points from 1990 to 1993 . This tighter policy was motivated by a shift in policy objectives rather than by overheating in the economy. According to the OECD surveys, the price stability goal caused Canada to keep policy tight despite the deep recession of the early $1990 \mathrm{~s}^{40}$

Spain experienced an unusually long, steady disinflation during much of the 1980s and 1990s..$^{41}$ The reason is summarized in a 1992 OECD survey: "following the 1982 devaluation, monetary policy shifted toward restriction and has remained tight overall since then." ${ }^{42}$ In 1994 the OECD reported "tight monetary conditions" despite a "deepening recession"; the tightness was motivated by "anti-inflation goals" and a desire to support the currency. ${ }^{43}$ In 1995 Spain was still adopting inflation targets calling for further disinflation.

IRELAND. The Irish success story is quite recent. Actual unemployment was 15.7 percent in 1993 and has fallen sharply since then. In some ways Ireland's experience fits my story well. Monetary policy has been fairly expansionary: although Ireland participated in the EMS, it devalued by 10 percent at the start of 1993, and real interest rates fell sharply over 1993-95. Output growth has been very strong, averaging about 5 percent a

40. See, for example, OECD (1991, pp. 45-50).

41. See Ball (1997).

42. $\operatorname{OECD}(1992$, p. 55).

43. OECD (1994c). 
year from 1987 through 1996, and the lowest annual rate of growth in this period was 2.2 percent in 1988 .

From the perspective of my story, the unusual part of the Irish experience is the behavior of inflation. Trend inflation fell from 3.6 percent in the first quarter of 1990 to 2.0 percent in the fourth quarter of 1992 and then stayed close to 2 percent. In contrast to the Netherlands, Portugal, and the United Kingdom, Ireland experienced no inflation runup to signal overheating in the economy. And indeed, serious overheating apparently did not occur. Ireland's rapid growth can be explained by a supply-side miracle: since the mid-1980s, total factor productivity has grown much faster than in other OECD countries. Aggregate demand is not the primary source of the rapid growth accompanying the fall in the NAIRU. (According to the OECD, the causes of rapid productivity growth include "foreign direct investment by multinational companies; an expanding well-qualified labor force; and a social consensus on pay policy that has left management free to concentrate on improving efficiency." ${ }^{44}$

A natural hypothesis is that Ireland's rapid productivity growth is somehow the cause of its falling NAIRU. If one looks outside the OECD, there is another country that suggests this idea: Chile, where rapid productivity growth in the 1990s has been accompanied by falling inflation and unemployment. The channels through which productivity growth might affect unemployment are not clear, but one possibility is wage demands. Authors such as Michael Bruno and Jeffrey Sachs blame rising unemployment in many countries in the 1970s on the productivity slowdown. ${ }^{45}$ They argue that demands for wage increases did not adjust immediately to the fall in productivity growth, and this caused an unfavorable shift in the unemployment-inflation tradeoff. Perhaps the reverse has occurred in Ireland and Chile, with wage demands not adjusting fully to productivity pickups. Another paper should investigate this idea in detail.

\section{Explaining the Results}

So far this paper has documented some empirical regularities about the forces leading to increases and decreases in the NAIRU. What can explain these facts?

44. OECD (1997, p. 13).

45. Bruno and Sachs (1985). 


\section{The Modeling Approach}

When previous authors have analyzed hysteresis, they have usually focused on channels through which current employment is affected by past employment. I take a somewhat different approach: I treat employment as exogenous and analyze the effects of employment movements on inflation. The reason is that the relation between employment and inflationthe Phillips curve-is the part of conventional macroeconomic models from which hysteresis theories must depart. If one looks at the real economy alone, textbook models are entirely consistent with the idea that a change in demand causes a permanent change in output and employment. If output is determined by an IS curve, it can fall for an indefinite period if the central bank raises the real interest rate and keeps it high, or if the central bank keeps the interest rate constant when the IS curve shifts. In textbook models, the forces that return output and employment to long-run equilibria are the Phillips curve and the behavior of policymakers. A deviation of output from its natural level causes accelerating inflation or deflation, and sensible policymakers respond by pushing output back. ${ }^{46}$

My model allows for hysteresis by modifying the textbook Phillips curve. The modification builds on an idea in previous work: the distinction between short- and long-term unemployment. Many authors argue that something happens to the long-term unemployed that makes them unlikely to find jobs: their human capital deteriorates, employers view them suspiciously, or they lose attachment to the labor force. Nickell and W. Franz argue that, because the long-term unemployed do not threaten to take jobs from other workers, they do not put downward pressure on wages. ${ }^{47}$ Thus the long-term unemployed do not affect inflation: the Phillips curve includes only short-term unemployment. Under this assumption there is a unique level of short-term unemployment consistent with stable inflation, but total unemployment can settle at any level.

46. This argument assumes that the central bank can hold the real interest rate at an arbitrary level indefinitely. In some rational expectations models this is an invalid assumption: even if policymakers can set nominal rates, jumps in inflation force the real interest rate to its equilibrium level. However, in textbook models - and in reality - there is enough inertia in inflation so that policymakers can control the real rate by adjusting the nominal rate. (This inertia might disappear if there were ever-accelerating inflation or deflation, but no such outcome will occur in my model.)

47. Nickell (1987); Franz (1987). 
This idea is supported by econometric evidence provided by Franz, Nickell, and the OECD. ${ }^{48}$ These studies estimate Phillips curves with separate terms for short- and long-term unemployment and find that the latter has little effect on inflation. This result is consistent with the fact that increases in the NAIRU in most countries have come disproportionately from increases in long-term unemployment. The equilibrium level of short-term unemployment appears relatively stable.

Although my model builds on previous work, I tailor it to fit the particular aspects of hysteresis uncovered in this paper. The first fact to explain is the result that a policy response to a recession can prevent a permanent rise in unemployment without a major cost in inflation. The second is the result that hysteresis is reversible: a demand expansion can reduce the NAIRU.

\section{Assumptions}

Here I describe the details of the model in several steps.

DEMAND-DETERMINED EMPLOYMENT. Let the size of the labor force be normalized to one, and let $E$ be the level of employment. Total unemployment is $1-E$. As discussed above, I consider an exogenous path of employment. One can interpret employment as being determined by aggregate spending, which in turn is determined by an IS equation. For the purposes of my theoretical analysis, it does not matter whether the demand shifts causing employment movements are caused by monetary policy or by shifts in the IS curve. ${ }^{49}$

SHORT- AND LONG-TERM UNEMPLOYMENT. Here I describe how movements in employment affect short-term and long-term unemployment. Short-term unemployment, $S$, is defined as workers in their first period of unemployment. Long-term unemployment is $1-E-S$. A "period" should probably be interpreted as a year, since applied work usually defines longterm unemployment as unemployment beyond a year.

48. Franz (1987); Nickell (1987); OECD Employment Outlook, 1993.

49. One can find deeper foundations for my approach in macroeconomic models with imperfect competition (see Romer, 1996, chapter 6). In these models, firms set prices in advance each period, so output is determined by demand. Firms are happy to accommodate increased demand with higher production and employment because price exceeds marginal cost. I assume the markup is sufficiently large that it is profitable to hire workers even if, as assumed below, firms pay small retraining costs for some of them. 
If $E$ increases from its level in the previous period, I assume that $E-E_{-1}$ new jobs are created, with workers hired from the unemployment pool. If $E$ falls, then $E_{-1}-E$ jobs are destroyed, and that many workers become unemployed. Finally, following search and efficiency-wage models, I assume a fixed rate of breakups of employer-employee matches in existing jobs. The breakup rate is $b$. The number of jobs continuing from the previous period is $\min \left(E, E_{-1}\right)$, so the number of matches that break up is $b\left[\min \left(E, E_{-1}\right)\right]$. I assume that it takes time to find a new job: workers whose matches break up cannot move to other jobs in the same period. Thus these workers become unemployed, and their jobs are filled from the previous period's unemployed.

Given the path of total employment, these assumptions determine shortterm unemployment:

$$
\begin{aligned}
S & =b E_{-1} & & \text { if } E \geq E_{-1} \\
& =E_{-1}-(1-b) E & & \text { if } E<E_{-1} .
\end{aligned}
$$

If employment does not decrease, the only workers in their first period of unemployment are those whose matches break up. If employment decreases, the short-term unemployed are those whose jobs are destroyed $\left(E_{-1}-E\right)$ plus those separated from the remaining jobs $(b E)$.

A steady state for the economy requires that $E=E_{-1}$, which implies that $S=b E$. Thus, in steady state, the ratio of short-term unemployment to employment equals the separation rate $b$.

THE PHILlips CURVE. The central assumption of the model is the Phillips curve. It is a conventional accelerationist equation, except that only short-term unemployment enters:

$$
\pi=\pi_{-1}-a(S / E-b), a>0,
$$

where $\pi$ is inflation and $\pi_{-1}$ is lagged inflation. According to this equation, inflation is constant when the ratio $S / E$ is at its steady-state level of $b$. Movements in $S / E$ cause inflation to move in the opposite direction.

As discussed above, this assumption is motivated by the idea that the long-term unemployed do not put pressure on wages. A number of specific labor market models might generate a Phillips curve like that in equation (2). For concreteness, I sketch a modification of a standard efficiency-wage model. Following Carl Shapiro and Joseph Stiglitz, suppose that wages are set at the level needed to elicit effort from workers, and that this level depends on the employment prospects of a worker who loses his or her 
job. ${ }^{50}$ If reemployment prospects improve, wages must be raised to maintain effort, and wage increases feed into higher inflation. ${ }^{51}$

Suppose also that, as in work by Blanchard and Peter Diamond, ${ }^{52}$ firms "rank" job applicants by their unemployment spells. When firms fill vacancies, they first hire those unemployed workers with the shortest spells of unemployment and then work up. Blanchard and Diamond discuss the evidence for such behavior, such as the dropoff in reemployment rates as unemployment spells lengthen. Firms behave this way because it is costly to hire the long-term unemployed - they need retraining, or it is costly to recruit them because they do not search intensively. Even if the cost of hiring the long-term unemployed is small, it still produces ranking because firms must pay the same wage to all workers. Workers are identical once the recruiting or retraining cost is paid, so they require the same wage to deter shirking.

These assumptions about efficiency wages and ranking imply a Phillips curve like equation (2). An employed worker knows that, if he loses his job, he will be one of the short-term unemployed. That worker's chances for reemployment depend on the number of short-term unemployed, but not on the long-term unemployed, because they are behind the worker in the job queue. Thus only short-term unemployment affects wage setting and inflation.

REEMPLOYMENT OF THE LONG-TERM UNEMPLOYED. The above assumptions are all I need to derive my results. It is worth commenting, however, on an implicit assumption that is built into the model. This assumption is that a sufficiently high level of demand leads firms to hire even the long-term unemployed. Firms turn to these workers when they exhaust the pool of short-term unemployed: they would rather pay a small retraining cost than leave jobs vacant. My story thus differs from hysteresis theories in which the long-term unemployed suffer such damage to their human capital or work ethic that they can never again work. Obviously, my assumption means that increases in unemployment are more easily reversible.

50. Shapiro and Stiglitz (1984).

51. This discussion glosses over the question of how higher real-wage demands feed into inflation-how a "wage curve" leads to a Phillips curve. This question arises for traditional Phillips curves as well as for my model. As discussed by Whelan (1997), one can answer the question by assuming that workers have backward-looking inflation expectations.

52. Blanchard and Diamond (1994). 
Once again, my assumption is motivated by empirical evidence. The experiences of the success countries show that strong demand does produce jobs for the long-term unemployed. In the United Kingdom, for example, as the unemployment rate fell from 11.6 percent in 1985 to 6.9 percent in 1997, the rate of long-term unemployment (spells exceeding a year) fell from 7.8 percent to 3.8 percent. The fall in long-term unemployment accounted for 4.0 percentage points of the 4.7 -percentagepoint reduction in total unemployment.

Thus in my model the long-term unemployed do not put pressure on wages (as suggested by the Phillips curve evidence), but they can be reemployed if demand is sufficiently strong (as suggested by the success countries). This is possible because of the small cost of hiring the longterm unemployed. With this cost, firms prefer the short-term unemployed to the long-term unemployed, making the latter irrelevant to wage determination, but they prefer to hire the long-term unemployed rather than hire nobody.

\section{Inflation and Alternative Employment Paths}

Here I derive the effects of alternative employment paths on inflation and compare the results with my empirical findings.

TEMPORARY VERSUS PERMANENT RECESSIONS. I first compare the effects of reducing employment temporarily and permanently. I use the results to interpret my findings about policy responses to recessions. The case of a permanent decrease in employment captures the experience of the E4 in the early 1980s, when employment fell and passive policy allowed it to stay low. The case of a temporary decrease captures the U.S.Canada pattern of a fall in employment followed by a policy-induced recovery. My main theoretical result is that, as in actual experience, there is little difference in the two scenarios' effects on inflation.

Table 8 summarizes the experiment. The table shows alternative paths of total employment and their implications for short-term unemployment and inflation. I assume the economy is in steady state in period zero, with $E$ and $\pi$ at initial levels $E_{0}$ and $\pi_{0}$ and the ratio $S / E$ at $b$. In period 1, employment falls to $x E_{0}, x<1$. I consider two scenarios for period 2: employment stays at $x E_{0}$, and employment returns to $E_{0}$. In both cases employment remains constant at its period-2 level after period 2 . 
Table 8. Effects of Permanent and Temporary Falls in Employment on Short-Term Unemployment and Inflation ${ }^{\mathrm{a}}$

\begin{tabular}{lcccc}
\hline Period & $E$ & $S$ & $S / E$ & $\pi-\pi_{0}$ \\
\hline 0 & $E_{0}$ & $b E_{0}$ & $b$ & 0 \\
1 & $x E_{0}$ & $(1-x+b x) E_{0}$ & $(1-x+b x) / x$ & $-a(1-x) / x$ \\
2 (permanent fall) & $x E_{0}$ & $b x E_{0}$ & $b$ & $-a(1-x) / x$ \\
2 (temporary fall) & $E_{0}$ & $b x E_{0}$ & $b x$ & $-a(1-x)(1 / x-b)$ \\
\hline
\end{tabular}

a. $E$ is employment, $S$ is short-term unemployment, $\pi$ is inflation, $b$ is the breakup rate of existing employer-employee matches, and $x$ is a constant less than one.

For each employment path, equation (1) determines the path of $S$; this path and the Phillips curve determine the path of inflation, which I express in terms of deviations from the initial level $\pi_{0}$. As shown in the table, inflation falls by an amount $a(1-x) / x$ in period 1 . If employment stays low in period 2, inflation stays constant in that period. If employment returns to $E_{0}$, inflation rises to a level that is $a(1-x)(1 / x-b)$ below the initial level.

Thus the model implies that either a temporary or a permanent fall in employment causes a permanent fall in inflation. The inflation decrease is larger if employment falls permanently, but not by much for plausible parameter values. The ratio of the inflation decrease when $E$ falls temporarily to when it falls permanently is greater than $1-b$. Recall that $b$ is the steady-state ratio of short-term unemployment to employment. For OECD countries in the 1980s and 1990s, a typical value of this ratio is $0.05 .{ }^{53}$ If $b=0.05$, then 95 percent of the inflation reduction from a permanent employment fall is achieved by a temporary fall. This result is consistent with my empirical finding that temporary and permanent employment reductions have similar effects on inflation.

My theoretical result can be explained as follows. When a recession destroys jobs, it initially creates short-term unemployment, which reduces inflation. If employment stays low, however, the short-term unemployed turn into long-term unemployed and stop putting pressure on inflation. At this point a demand expansion can bring people back to work without giving up much inflation reduction.

DEMAND EXPANSIONS. The model also implies that a demand expansion raises employment permanently with modest inflationary costs. Table 9 shows what happens if employment rises from $E_{0}$ in period zero 
Table 9. Effects of a Rise in Employment on Short-Term Unemployment and Inflation ${ }^{\text {a }}$

\begin{tabular}{lcccc}
\hline Period & $E$ & $S$ & $S / E$ & $\pi-\pi_{0}$ \\
\hline 0 & $E_{0}$ & $b E_{0}$ & $b$ & 0 \\
1 & $x E_{0}$ & $b E_{0}$ & $b / x$ & $a b(x-1) / x$ \\
2 & $x E_{0}$ & $b x E_{0}$ & $b$ & $a b(x-1) / x$ \\
\hline
\end{tabular}

a. $E$ is employment, $S$ is short-term unemployment, $\pi$ is inflation, $b$ is the breakup rate of existing employer-employee matches, and $x$ is a constant greater than one.

to $x E_{0}$ in period 1, where here $x>1$, and then remains constant. Using equations (1) and (2), the table shows that inflation rises by $a b(x-1) / x$. This increase is much smaller than the inflation decrease caused by a fall in employment. Tables 8 and 9 imply that the ratio of the inflation increase from a permanent rise in $E$ to the reduction from a permanent fall in $E$ by the same percentage is less than $b$. Again, a plausible value of $b$ is 0.05 . Thus the model captures the fact that demand expansions raised inflation in the Netherlands, Portugal, and the United Kingdom, but not by as much as contractions reduce inflation.

Indeed, the theoretical result is overly strong. In practice, the inflation effects of employment increases are smaller than those of employment decreases, but the ratio of these effects is larger than 0.05. The inflation runups in the Netherlands, Portugal, and the United Kingdom were not trivial. In the model, an increase in employment from a demand expansion comes entirely from a decrease in long-term unemployment: when employment rises, short-term unemployment is a fixed proportion of previous employment. The ratio $S / E$ falls somewhat, raising inflation, but only because the denominator rises. In reality, an increase in employment is not accounted for entirely by a decrease in long-term unemployment. A realworld expansion causes a decrease in the separation rate (which I treat as fixed) as well as an increase in hiring. Fewer separations mean less shortterm unemployment, and hence a greater rise in inflation. Future research can extend my model to capture these ideas and try to fit the facts more precisely. ${ }^{54}$

54. If the effect of expansions on separations is strong enough, some of my main results change; for example, a recession cannot reduce inflation permanently unless it raises unemployment permanently. My qualitative results depend on the assumption that changes in separations play a smaller role in employment increases than in employment decreases. This assumption is supported by U.S. evidence in Foote and Shin (1999). 


\section{Conclusion}

This paper has argued that monetary policy and other determinants of aggregate demand have long-run effects on unemployment. Throughout the OECD, the reactions of policy to recessions in the early 1980s helped determine whether unemployment rose temporarily or permanently. And since 1985, demand expansions have reduced long-run unemployment in several countries.

To conclude, I compare my story with those of other authors and then discuss policy implications.

\section{Comparisons with Recent Literature}

Here I discuss several recent papers on unemployment in the OECD countries.

BALL (1997). The present paper reinforces the message of my previous paper that aggregate demand has important effects on long-run unemployment. I find here that demand expansions can reduce unemployment just as contractions can raise it.

The present paper also suggests a new interpretation of one of my earlier results. The 1997 paper found that disinflations cause larger increases in the NAIRU if they last a long time. The data in the present paper show that countries with long disinflations are those that keep monetary policy tight despite the onset of recessions. Continuing tight policy means that inflation falls for longer, although the additional decrease is small. And continuing tight policy means that the cyclical rise in unemployment becomes permanent.

BLANCHARD AND WOLFERS (1999). This paper and another by Blanchard emphasize that shocks as well as institutions are important for explaining unemployment. ${ }^{55}$ In a broad sense I make a similar point by arguing that the direct effects of labor market institutions have been overemphasized. One kind of shock discussed by Blanchard and Wolfers is shifts in aggregate demand, which they measure by changes in inflation. However, they follow the conventional wisdom in interpreting demand-driven movements in unemployment as deviations from a longrun equilibrium. They implicitly deny that demand affects the NAIRU. 
(They do not even cite Blanchard and Summers' work on hysteresis!) According to Blanchard and Wolfers, the shocks that shift the NAIRU are real shocks such as the productivity slowdown.

Another of the Blanchard-Wolfers shocks is the increase in real interest rates in the 1980s. At first glance, blaming unemployment on high interest rates seems consistent with my story. But following Edmund Phelps ${ }^{56}$ Blanchard and Wolfers emphasize nontraditional supply-side channels through which interest rates affect employment. In my story interest rates affect employment through aggregate demand.

GORDON (1999). From the aftermath of the 1992 breakup of the European Exchange Rate Mechanism (ERM), Robert Gordon argues that there is no "macroeconomic free lunch": expansionary monetary policy cannot reduce unemployment without raising inflation. Gordon's view conflicts with my finding that NAIRU-reducing demand expansions have modest effects on inflation. (In my story, the lunch is very inexpensive, if not absolutely free.) In my opinion, Gordon's analysis is flawed because he equates a decision to leave the ERM with a generally expansionary monetary policy. In fact, the "leaver" countries include several with tight policy_notably Finland and Sweden, which replaced exchange rate targets with inflation targets requiring sharp disinflations. The "stayers," on the other hand, include the Netherlands, which, as discussed earlier, was able to follow a fairly expansionary policy while remaining in the ERM. Comparing ERM leavers and stayers is not a fair test of the effects of expansionary policy.

COUNTRY STUDIES. In discussing individual countries, a number of authors argue that aggregate demand affects long-run movements in unemployment. Discussions that I find persuasive include those of Pierre Fortin and Adam Posen on rising unemployment in Canada and Japan, respectively, and Asbjorn Rodseth on low unemployment in Norway. ${ }^{57}$ The detail in these studies complements my argument based on cross-country evidence.

\section{Policy Implications}

In setting policy, central banks should take account of the long-run effects on unemployment. In particular, my results imply a strong case for com-

56. Phelps (1994).

57. Fortin (1996); Posen (1998); Rodseth (1997). 
bating recessions with expansionary policy. Failing to do so can produce not only a deeper recession, but also a permanent rise in unemployment.

What should policymakers do if unemployment has settled at a high level? The experiences of the success countries suggest that some kind of demand expansion is desirable. The details of the ideal policy are not clear, however. The expansions in the success countries were largely accidental-they began with shocks to spending that were not caused by policy. Perhaps an intentional monetary easing could be designed to produce even better outcomes, such as a fall in unemployment with a smaller runup in inflation. Future research should address this issue.

The results in this paper do not refute the view that major labor market reforms would reduce unemployment. Reforms in the 1980s and 1990s have not had large effects, but most of the reforms have been minor. Radical reforms such as a drastic reduction in UI duration might make a difference.

Labor market reforms might complement demand expansions. Unemployment is most likely to fall when the unemployed are given incentives to seek work and a strong economy creates jobs for them to find. In addition, incomes policies might dampen the inflationary effects of demand expansions, as suggested by Franco Modigliani..$^{58}$ This may have happened already in the Netherlands. Labor market and monetary policies could be complementary at a political level as well. One can imagine a bargain in which workers accept wage restraint and UI reductions and the central bank promises a monetary policy that creates jobs. 


\section{Comments and Discussion}

N. Gregory Mankiw: I would like to start my discussion of this paper by ignoring it for a moment and considering the problem currently (as of early September 1999) facing Federal Reserve Board Chairman Alan Greenspan. As has been widely noticed, unemployment in the United States is now far lower than most economists considered possible even a few years ago. It was not very long ago that estimates of the NAIRU (or, to use an alternative term, the natural rate of unemployment) for the U.S. economy ranged from 5.5 percent to over 6 percent. Yet U.S. unemployment has been below 5 percent for several years, and it is now close to 4 percent. Nonetheless, to the surprise of many of us, inflationary pressure is hard to find.

These are, of course, fortunate developments. The problem Greenspan faces is judging whether they are going to last. Imagine that the Fed staff produced a report showing convincingly that the NAIRU really was still 5.5 percent and that the low inflation of recent years was attributable to a series of favorable but temporary supply shocks, such as falling commodity prices due to the Asian slump. Greenspan would probably respond to this news by raising interest rates, knowing that unless he did, higher inflation was around the corner. On the other hand, imagine that the Fed staff produced a convincing report concluding that the NAIRU had actually fallen to 4 percent and would likely keep falling because of, say, the aging of the population. In this case Greenspan would start worrying less about inflation and would forgo the increase in interest rates. He might even be tempted to cut rates a bit.

Nothing in what I have just said is terribly surprising. It is, in fact, the standard analysis of the current U.S. situation, and I suspect Laurence 
Ball would agree with it. But this analysis has an important implication: News about the NAIRU influences the monetary policy that the central bank pursues. When the NAIRU falls, the central bank is given more room to pursue an expansionary policy of increasing the money supply and cutting interest rates. Conversely, when the NAIRU rises, the central bank is more likely to keep monetary policy tight to maintain control over inflation.

What does all this have to do with this paper? Quite a lot, I think. The central fact of this paper is that countries that failed to pursue expansionary monetary policy during the recessions of the early 1980s experienced larger increases in their NAIRUs than did countries that did pursue such a policy. Ball interprets this fact as a challenge to standard theory, according to which monetary policy has only short-run effects on unemployment, and as evidence for long-run effects of aggregate demand. An alternative interpretation, however, puts causation in the other direction: Countries that experienced large increases in their NAIRUs were induced to pursue less expansionary monetary policy. This alternative interpretation of Ball's evidence is in line with the description of Greenspan's current problem that I started with.

Let me put the same issue in more formal, econometric terms. In his table 5, Ball presents results from regressing the change in a country's NAIRU on a measure of its monetary policy (the change in real interest rates during a recession) and a measure of its labor market policy (the duration of unemployment insurance). The significant coefficient on the monetary policy variable captures the central result of this paper, which Ball interprets as showing that monetary policy influences the NAIRU. But of course this regression is estimated by the ordinary least-squares method, so it is valid only if the true residual is uncorrelated with the right-hand side variables. In particular, shocks to the NAIRU have to be unrelated to monetary policy. That might be true, but it would not be my first guess. And it certainly is not an identifying assumption that I would feel comfortable using to discredit standard theory, as Ball tries to do in this paper.

I do not mean to imply that my alternative interpretation is right and Ball's is wrong. I only mean to suggest that the matter is far from settled. My alternative interpretation of the evidence is based on exogenous changes in the NAIRU that monetary policymakers respond to. Ball's interpretation is based on exogenous differences in monetary policy that, for reasons left out of standard theory, influence the economy's long-run 
unemployment rate but have insignificant effects on inflation. Occam's razor does point toward my less radical view, for it does not require a major revision and complication of macroeconomic theory, but in the absence of any truly exogenous instrument to test the competing theories, there is no way to be sure.

Ball believes that one can settle the issue by examining the rhetoric offered by the central banks. He argues that by reading how central bankers explain their actions, we can judge whether differences in policy are exogenous random events or endogenous responses to economic developments. I wish it were so easy. Rhetoric, too, is endogenous. A central bank facing a recession due to inadequate aggregate demand is likely to put forward more antirecessionary rhetoric than a central bank facing a recession due to an increase in the natural rate. When a central bank thinks it can hit the ball out the park, it steps up to the plate. When it thinks it is going to strike out, it may not even show up for the game.

So my first reaction to this paper is that I am not convinced by the key motivating fact. I am, however, intrigued by the model that Ball eventually builds up to. In particular, the idea that long-term and short-term unemployment might have different roles in the inflation process seems plausible to me. That idea deserves a careful hearing. I say this because long-term unemployment seems like a different phenomenon than shortterm unemployment. A person who just lost his or her job because of a corporate downsizing, for instance, is probably looking hard for a new one. A person who has been unemployed for a year or more may have given up an intensive job search and might more realistically be counted as out of the labor force.

Alternatively, perhaps such a person should really be counted as employed. This possibility was suggested to me by a professor from Ireland who visited Harvard last year. The Irish professor, who, like me, had several small children, told me that one advantage of living in Ireland was the great supply of child care workers willing to work at low wages. He explained that large numbers of young Irish women are living on the dole as long-term unemployed while working full-time as nannies. Obviously, this employment masquerading as unemployment shows up as a higher measured NAIRU. Whether it is affected by monetary policy the professor did not say.

I hope that in future work Ball will develop the implications of his new Phillips curve model more completely. One possible area to explore 
concerns strategies for reducing inflation. An issue hotly debated in the late 1970s was whether policymakers facing high inflation should try to reduce it gradually or eliminate it quickly. Ball's model seems to argue for the cold-turkey approach, because trying to reduce inflation gradually pushes many workers into long-term unemployment, which does little to reduce inflation. This theoretical result is, I should note, consistent with an empirical finding in one of Ball's earlier papers that rapid disinflations are less costly (as measured by standard sacrifice ratio calculations) than gradual ones. ${ }^{1}$

I also wonder what Ball's model says about optimal macroeconomic policy. In particular, does this model say that stable employment is the most desirable path for the economy? Or might some amount of fluctuation be a good thing, for then temporary booms can pull people out of long-term unemployment? To be more precise, here is a question one might ask: Which path, one of stable or one of fluctuating employment, produces the highest average employment (holding constant the terminal inflation rate)? Given all its nonlinearities, this model does not seem to exhibit the strongest form of the natural rate hypothesis, according to which average employment is completely invariant to monetary policy. But from what the paper says, I am not really sure what an employmentmaximizing monetary policy would look like.

Ball might also think about whether his model generates any new and interesting testable predictions that we might bring to the data, as opposed to just explaining the facts that motivate the model. His model suggests that monetary shocks have different effects depending on the stage of the business cycle. One can imagine an empirical study that applies timeseries techniques to try to identify these nonlinearities. There has been a bit of empirical work showing that monetary shocks have asymmetric effects-that is, positive shocks do not have precisely the opposite effect of negative shocks. ${ }^{2}$ This is not the same nonlinearity that Ball's model predicts, but this result does suggest that there is some hope of finding significant nonlinearities in the aggregate time series.

The evidence in this paper is valuable for being both straightforward and thought-provoking. And certainly the issues Ball takes on here are among the most important in economics. Although I am not ready to

1. Ball (1994).

2. Cover (1992). 
accept his interpretation of the facts, neither am I ready to reject it. I am open to the possibility that his view is right - that aggregate demand does have long-lived effects on employment and production. The evidence presented here, however, does not convince me to sign on yet.

William D. Nordhaus: Anyone who follows both mainstream macroeconomics and the newspapers knows that the textbook model of the wage-price-unemployment process is in trouble. By the textbook model, I mean the standard accelerationist Phillips curve centered on a stable NAIRU determining wage inflation.

What is the trouble? In the United States, the puzzle is the low inflation that has persisted through the long expansion and low unemployment of the late 1990s. Economic studies from earlier periods suggested that wage and price inflation would begin to rise when unemployment fell below its lowest sustainable rate, generally thought to be somewhere between 5 and 6 percent of the labor force. Unemployment fell below 5 percent three years ago. Yet inflation has actually declined slightly since then. In Europe, the textbook model is in even deeper water: nothing resembling plausible or stable NAIRUs can be found for most countries.

When faced with an anomaly, economists can either find special factors to account for it, or look for another theory. The Brookings Panel often leans to the special-factors approach. It has been employed through many vintages by Robert Gordon, most recently in his paper on the Goldilocks economy. ${ }^{1}$ Lawrence Katz and Alan Krueger sound a similar theme in their recent Brookings Paper on labor markets. ${ }^{2}$

The orthodox view of the recent U.S. experience runs as follows:

- The 1990s saw an unusually muted response of wages to low unemployment. One reason was that a more experienced work force and a larger prison population reduced the fraction of the labor force in highunemployment groups and thereby lowered the NAIRU. A decline in labor unions may have lowered wage pressures. Some also believe that the American work force has become cowed in the face of more aggressive management.

1. Gordon (1998).

2. Katz and Krueger (1999). 
-On the price side, oil and commodity prices declined as the world went through a deep recession. When weak demand abroad was added to an appreciating dollar, import prices into the United States actually fell. Additionally, a rebound in labor productivity growth reduced the growth of unit labor costs and of prices for domestically produced goods and services.

-One new factor was the growing globalization of production. As the United States becomes more integrated in world markets, domestic firms find their ability to raise prices constrained by the low prices of international competitors. Even with domestic sales of automobiles booming, domestic automakers cannot raise their prices or wages by much for fear of losing market share to Japanese and other foreign producers.

I suppose one could take the same approach to European unemployment and look for special factors, particularly labor market policies, to rescue the basic framework. This seems a fool's errand, however, and has seldom been followed.

The usual approach taken to explain European unemployment has been to posit that the NAIRU is neither constant nor stable but changes markedly over time in response to macroeconomic structure and policies. A vast literature works this side of the street-one associates the names of Olivier Blanchard, Stephen Nickell, and Edmund Phelps with the view that the NAIRU varies over time with changes in interest rates, labor market policies, unionism, and other factors. My reading pretty much conforms to that of Laurence Ball in concluding that these studies have not been terribly successful in explaining changes or differences in unemployment.

Ball argues that the textbook model is in trouble, and he clearly takes the second approach — rejecting the constant NAIRU—-to explaining inflation and unemployment behavior. His approach is to build upon what are called hysteresis models.

I have a few complaints about some of the details of the paper. One problem involves the somewhat loose discussion of the variables. The discussion focuses on the impacts of monetary policy, yet the underlying model is really about changes in aggregate demand or capacity utilization. I fail to see the point of the attempt in the early part of the paper to identify policy changes. I found myself unhappy with the treatment of monetary policy for countries outside the United States, particularly in Europe. The role of exchange rate policy is given insufficient attention, yet the interaction of monetary policy and exchange rate policy would be 
critical for some countries. Surely, for the case of the Netherlands, with its hard peg to the German mark, it makes little sense to talk about the reaction of monetary policy to recessions. The same is true of most other countries to different degrees in different periods.

It is also worth recalling that estimating NAIRUs is a treacherous business and that some of the NAIRU changes that Ball analyzes may simply be errors in measurement. I have some difficulty accepting a procedure that yields a NAIRU for Switzerland of percent and a NAIRU for Spain of 18 percent. I also have difficulty swallowing an increase in the German NAIRU from 1 or 2 percent in the 1960s to 8 percent in the 1990s.

There is some fuzziness in the discussion of the NAIRUs. Are these wage NAIRUs or price NAIRUs? Surely we should be analyzing wage NAIRUs. Similarly, I would prefer to examine wage inflation rather than price inflation, because many changes in price inflation involve many non-labor market influences, and that point gets overlooked.

Turning to the core of the paper, I do think that Ball is onto something important and interesting in pointing to the role of the duration of unemployment in understanding wage-unemployment dynamics. To understand what Ball is proposing, remember that the standard Phillips curve model uses the conventional unemployment rate to measure the pressure of demand in labor markets. In effect, this assumes that every unemployed worker puts the same downward pressure on wage increases, whether that worker is a high-wage computer scientist, a unionized steelworker, or a teenager loosely attached to the labor force. The model assumes, moreover, that anyone who is out of the labor force puts no pressure on wages. I doubt that anyone really believes such an oversimplified model. There is a long tradition, going back to George Perry's studies of wage behavior, that develops alternative measures of unemployment. But as long as the structure of unemployment is stable, putting different weights on different people would make little difference.

Ball's suggestion is to redefine the unemployment rate when we are trying to understand wage dynamics. He would put only the short-term unemployment rate in the Phillips curve. His defense of this is somewhat cursory, but we might well take this approach if we believe that workers become discouraged and loosely attached to the labor force as their unemployment duration lengthens. In effect, Ball draws the line between active and inactive participants in the labor market differently from that used in standard definitions. 
I do not think Ball's model does justice to the complicated dynamics of unemployment, nor does his analysis of the impact of changes in demand seem quite right to me. The model has only two periods and therefore does not really capture the impact of changes in labor market policies or changes in demand on the duration of unemployment.

The most interesting and complex issue involves the relationship between employment dynamics and wage behavior. We are not allowed to use differential equations in Brookings Papers comments, so I will have to put this in English. Ball assumes the polar case of "LIFO" reemployment - the last fired are the first rehired. This means that the unemployed are vintaged, with recent separations always going to, and employers always hiring from, the top of the barrel.

We can think of the wage dynamics as operating in two regimes. In normal times, employers are simply hiring the short-term unemployed, and wage inflation is symmetrical in expansions and contractions. I am not sure Ball's discussion of short-run changes is consistent with this more complex model.

The interesting new regime operates either in long expansions or in long contractions. In long expansions, employers dip deeper and deeper into the unemployment barrel, and the number of long-term unemployed decreases. In long contractions, the number of long-term unemployed at the bottom of the barrel increases. These increases or decreases do not affect wages, however, so the contraction is for anti-inflationary naught, and policy has found the holy grail of an inflation-free expansion.

Ball argues that his approach turns into a hysteresis model once we recognize the complicated dynamics of long-term and short-term unemployment. It is not clear to me that his is genuinely a hysteresis model. Rather, it seems that, because the conventional Phillips curve model has the wrong independent variable, it requires a complicated inversion of the lag structure to uncover the unemployment-inflation relationship.

Put differently, if there is a stable set of flow relationships connecting short-term and long-term unemployment, then the long-run inflationunemployment tradeoff is independent of history, and the long-run NAIRU is unaffected by demand. It would be the case, however, that the short-run NAIRU depends upon the history of employment and unemployment.

What does all this imply for policy? The main implication of Ball's approach is that anti-inflation policy should focus on maximizing shortterm unemployment, given that increases in long-term unemployment 
have little impact upon inflation. If this is correct, it has fundamental implications for the conduct of stabilization policy. Although Ball does not work out the optimal anti-inflation policy, I would label his approach the Powell-Ball doctrine for economic stabilization:

Use massive and overwhelming recessionary force to overwhelm the inflationary enemy. Conduct a short and vicious war. Take many prisoners, but let them go after a few months. Stun workers but do not maim them. They should return to the negotiating table bloodied by the recent memory of unemployment. Above all, avoid a European-style war of attrition in which you keep long-term unemployment high for extended periods.

All this is fascinating. But it remains more suggestive than convincing, because the evidence in the paper is thin and the modeling primitive. We need much more evidence to show that short-term unemployment will improve upon the conventional measure everywhere and always, or even anywhere and sometime. Sifting through the evidence will be a long and tedious process. But as someone once said, that's why God made graduate students.

General discussion: William Dickens discussed how a model of nominal wage rigidity with a sufficiently large variance of desired wage changes would fit the stylized facts that the paper attempted to explain. In such a model, low inflation may be associated with high unemployment, and a positive aggregate demand shock may raise inflation and lower unemployment as in a standard Phillips curve. But a positive productivity shock will permit faster nominal wage growth and lower unemployment without price inflation. Dickens reported that estimates of such a model for several OECD countries were more stable and required fewer special dummies than standard Phillips curve estimates.

Edmund Phelps observed that most researchers who had studied Europe's economies remained skeptical about the importance of hysteresis effects for unemployment. Along with statistical reasons for rejecting it, there is the fact that the standard adverse effects are offset by a large favorable one: with poor job prospects, people continue their education for longer than they otherwise would, effectively taking themselves out of the unemployment pool. Phelps also questioned the paper's finding on monetary policy because it ignored the large literature that uses variables such as the world real interest rate, real exchange rates, wealth, the relative price of energy, and tax rates in explaining unemployment. He also found plausible 
Gregory Mankiw's observation that expansionary monetary policy was useful in the United States because the natural rate kept falling, whereas in Europe there were no such favorable changes in the natural rate to exploit.

Alan Blinder said he found hysteresis models useful in explaining the 1970s and 1980s, when tight stabilization policies were followed by chronic increases in unemployment in many European countries. However, he stressed that most European economists did not share this view and would agree with the reverse causation argument articulated by Mankiw. He suggested two case studies that might shed light on this disagreement. One is the dramatically different experiences of Britain and France after 1992, when Britain left the ERM while France stayed in it. Although Britain's decision to quit was not an exogenous event, it may have had more to do with politics than economics. The other case is that of the U.S. economy since 1996, a period in which it has widely outperformed predictions from NAIRU models. Blinder characterized this period as an unexpected boom rather than one in which the Federal Reserve perceived that the natural rate was dropping and eased accordingly. William Brainard agreed, noting that the Fed kept making wrong forecasts, was then surprised by how well the economy did, and decided to hold off any tightening, in effect showing disbelief in the NAIRU. However, Mankiw argued that, if inflation had worsened, the Fed would have tightened, revealing the kind of endogenous response that creates a problem for the estimates in the paper, whose validity depends on policy being exogenous.

While accepting the potential for long-run effects of monetary policy, Lawrence Katz found the evidence in the paper inconclusive. He agreed that simple correlations with institutional differences could not explain much. In the 1950s and 1960s, many countries with relatively rigid labor market institutions had low unemployment rates. In the 1990s, countries with relatively flexible labor markets, like the United States, had the lowest unemployment rates. However, he also noted that the correlation between rigid institutions and the tendency of negative shocks to persist over time, which Ball regarded as spurious, might instead reflect interactions between negative shocks and institutional rigidities. Shocks could plausibly produce worse outcomes in systems where insiders have more power and outsiders are disenfranchised by restrictive hiring and firing practices, and in systems with generous long-term unemployment benefits. Furthermore, he reasoned that technology growth, globalization, and the improved ability 
of firms to move abroad may have changed the interactions between institutions and shocks.

Christopher Carroll was skeptical of relying on aggregate demand explanations for long-term labor market outcomes. Like Katz, he suggested that the interaction of institutional factors with real shocks might account for the unemployment disparities of recent years. Specifically, the European labor market rigidities that were not a problem in the first postwar decades of high productivity growth may have become a source of chronic unemployment when productivity growth slowed. Carroll added that the Akerlof-Dickens-Perry model could explain how a productivity slowdown interacts with labor market institutions to increase unemployment. Austan Goolsbee argued that the paper was unfair to structural explanations of labor market developments across countries. He noted that very low effective tax rates, given generous tax exemptions for foreign companies, have been a large factor in the recent surge in foreign direct investment and productivity growth in Ireland.

David Laibson focused on the assumption in the paper's model that firms prefer to hire short-term rather than long-term unemployed. He noted that, besides the depreciation of human capital that comes with long-term unemployment, which is the effect the paper focuses on, there are important income effects that make unemployed workers more eager to take jobs. Subsidies from the state, unemployment insurance, and private savings all decrease over the duration of unemployment. Thus he suggested that a test of Ball's model would be to see whether Phillips curve effects from the long-term unemployed were weaker in countries with strong social safety nets than in countries with weak ones. James Duesenberry noted that it was a mistake to sort the unemployed by duration without recognizing other important differences between the short-term and the long-term unemployed. Long-term unemployment is concentrated in depressed regions or declining industries, so that the affected workers cannot be modeled as though they were in similar circumstances to other workers except for the duration of their unemployment spells.

Robert Hall saw the paper, along with the early work of Blanchard and Summers on hysteresis, as reinforcing the view that the NAIRU, and the natural rate of unemployment itself, are not useful ideas. The NAIRU is supposed to be invariant to monetary policy. Policy affects demand and moves the economy along the Phillips curve, and the NAIRU is the location 
parameter of the Phillips curve. The paper's contrary view, according to which monetary policy affects the NAIRU, cannot be reconciled with that concept of NAIRU or with a stable natural rate. Hall went on to argue for more broad-minded research, noting that unemployment shows no tendency to return to a natural rate in any country except the United States and that wage pressures bear no relation to unemployment rates across different labor markets in the United States. Whether monetary policy may be a cause of shifts in the equilibrium unemployment rate, as argued in the paper, remained an open question. 


\section{References}

Ball, Laurence. 1994. "What Determines the Sacrifice Ratio?” In Monetary Policy, edited by N. Gregory Mankiw. University of Chicago Press.

. 1997. "Disinflation and the NAIRU." In Reducing Inflation: Motivation and Strategy, edited by Christina Romer and David Romer. University of Chicago Press.

Blanchard, Olivier. 1997. "Comment on Disinflation and the NAIRU.” In Reducing Inflation: Motivation and Strategy, edited by Christina Romer and David Romer. University of Chicago Press.

. 1999. "European Unemployment: The Role of Shocks and Institutions." Baffi Lecture, Rome.

Blanchard, Olivier, and Peter A. Diamond. 1994. "Ranking, Unemployment Duration, and Wages." Review of Economic Studies 61(3): 417-34.

Blanchard, Olivier, and Juan F. Jimeno. 1995. "Structural Unemployment: Spain versus Portugal.” American Economic Review 85(2): 212-18.

Blanchard, Olivier, and Lawrence H. Summers. 1986. "Hysteresis and the European Unemployment Problem." In NBER Macroeconomics Annual, edited by Stanley Fischer, 1: 15-78.

Blanchard, Olivier, and Justin Wolfers. 1999. "The Role of Shocks and Institutions in the Rise of European Unemployment: The Aggregate Evidence.” Working Paper 7282. Cambridge, Mass.: National Bureau of Economic Research (August).

Boschen, John F., and Leonard O. Mills. 1991. "The Effects of Countercyclical Monetary Policy on Money and Interest Rates: An Evaluation of Evidence from FOMC Documents.” Working Paper 91-20. Philadelphia: Federal Reserve Bank of Philadelphia (October).

Bruno, Michael, and Jeffrey Sachs. 1985. Economics of Worldwide Stagflation. Harvard University Press.

Cover, James Peery. 1992. "Asymmetric Effects of Positive and Negative MoneySupply Shocks." Quarterly Journal of Economics 107(4): 1261-82.

Elmeskov, Jorgen. 1993. "High and Persistent Unemployment: Assessment of the Problem and Its Causes." Working Paper 132. Paris: Economics Department, Organization for Economic Cooperation and Development.

Elmeskov, Jorgen, John P. Martin, and Stefano Scarpetta. 1998. "Key Lessons for Labor Market Reforms: Evidence from OECD Countries' Experiences.” Unpublished paper. Organization for Economic Cooperation and Development.

Foote, Christopher L., and John Shin. 1999. "Reconciling Manufacturing and Non-Manufacturing Gross Job Flows.” Unpublished paper. Harvard University.

Fortin, Pierre. 1996. "The Great Canadian Slump." Canadian Journal of Economics 29(4): 761-87. 
Franz, W. 1987. "Hysteresis, Persistence, and the NAIRU: An Empirical Analysis for the Federal Republic of Germany." In The Fight Against Unemployment, edited by R. Layard and L. Calmfors. MIT Press.

Gordon, Robert J. 1998. "Foundations of the Goldilocks Economy: Supply Shocks and the Time-Varying NAIRU." BPEA 2:1998, 297-333.

— 1999. "The Aftermath of the 1992 ERM Breakup: Was There a Macroeconomic Free Lunch?" Working Paper 6964. Cambridge, Mass.: National Bureau of Economic Research (February).

Junankar, P. N., and Jakob Madsen. 1996. "Unemployment in the OECD: Models and Mysteries." Southampton, U.K.: University of Southampton Discussion Paper in Economics and Econometrics 9648 (November).

Katz, Lawrence F., and Alan B. Krueger. 1999. "The High-Pressure U.S. Labor Market of the 1990s." BPEA 1:1999, 1-65.

Layard, Richard, Stephen Nickell, and Richard Jackman. 1991. Unemployment: Macroeconomic Performance and the Labour Market. Oxford University Press.

Modigliani, Franco. 1996. "The Shameful Rate of Unemployment in the EMS: Causes and Cures." De Economist 144(3): 363-96.

Nickell, Stephen J. 1987. "Why Is Wage Inflation in Britain So High?” Oxford Bulletin of Economics and Statistics 49(1): 103-28.

_. 1997. "Unemployment and Labor Market Rigidities: Europe versus North America." Journal of Economic Perspectives 11(3): 55-74.

OECD (Organization for Economic Cooperation and Development). 1983. OECD Economic Surveys: France. Paris.

OECD. 1988. OECD Economic Surveys: United Kingdom, 1987-88. Paris.

OECD. 1989a. OECD Economic Surveys: Spain, 1988-89. Paris.

OECD. 1989b. OECD Economic Surveys: United Kingdom, 1988-89. Paris.

OECD. 1991. OECD Economic Surveys: Canada, 1990-91. Paris.

OECD. 1992. OECD Economic Surveys: Spain, 1991-92. Paris.

OECD. 1994a. The OECD Jobs Study. Paris.

OECD. 1994b. OECD Economic Surveys: Belgium-Luxembourg, 1993-94. Paris.

OECD. 1994c. OECD Economic Surveys: Spain, 1993-94. Paris.

OECD. 1995. OECD Economic Surveys: Portugal, 1994-95. Paris.

OECD. 1997. OECD Economic Surveys: Ireland, 1996-97. Paris.

Phelps, Edmund. 1994. Structural Slumps: The Modern Equilibrium Theory of Unemployment, Interest and Assets. Harvard University Press.

Posen, Adam. 1998. Restoring Japan's Economic Growth. Washington: Institute for International Economics.

Rodseth, Asbjorn. 1997. "Why Has Unemployment Been So Low in Norway? The Potential of Macroeconomic Explanations." In Making Solidarity Work: The Norwegian Labour Market Model in Transition, edited by J. Dolrik and A. Steen. Oslo: Scandinavian University Press. 
Romer, Christina, and David Romer. 1994. "What Ends Recessions?" In NBER Macroeconomics Annual, edited by Stanley Fischer and Lulio Rotemberg, 9: $13-57$.

Romer, David. 1996. Advanced Macroeconomics. McGraw-Hill.

Shapiro, Carl, and Joseph E. Stiglitz. 1984. "Equilibrium Unemployment as a Worker Discipline Device.” American Economic Review 74(3): 433-44.

Sichel, Daniel E. 1994. "Inventories and the Three Phases of the Business Cycle." Journal of Business and Economic Statistics 12(3): 269-77.

Siebert, Horst. 1997. "Labor Market Rigidities: At the Root of Unemployment in Europe." Journal of Economic Perspectives 11(3): 37-54.

Taylor, John B. 1993. "Discretion versus Policy Rules in Practice." CarnegieRochester Conference Series on Public Policy 39: 195-214.

Whelan, Karl. 1997. "Wage Curve versus Phillips Curve: Are There Macroeconomic Implications?" Working Paper 51. Finance and Economics Discussion Series. Washington: Federal Reserve Board of Governors (September). 
